\title{
Assessing the User Needs of STEM Graduate Students: A Comparative Analysis
}

\author{
Adelia Grabowsky and Juliet Rumble \\ Auburn University, USA
}

\begin{abstract}
This paper reports on findings of a local version of the Ithaka S+R Graduate and Professional Student Survey administered at Auburn University during the 2018 spring semester. It offers a comparative analysis of the survey responses of Auburn STEM and non-STEM graduate students, with a focus on questions related to (a) patterns of information discovery and usage, (b) research skills that respondents believe contribute to academic and professional success, and (c) respondents' perceptions regarding the library's role in supporting different parts of the research cycle. The authors reflect on the implications that disciplinary differences in research practices and expectations have for research support services tailored to the specific needs of STEM students.
\end{abstract}

\section{Introduction}

Graduate students are significant contributors to research activity on university campuses, and their professional education is central to the mission of their home institutions. Supporting the research needs of this population is thus of prime importance for academic libraries. However, graduate students are not a monolithic group. As library services for graduate students have expanded from providing access to collections to offering support throughout the entire research cycle, understanding disciplinary differences in researcher practices and expectations has proven vital to effective liaison services.

At Auburn University, students enrolled in STEM fields make up a significant portion of the graduate student population. Auburn is a land-grant and public research university with graduate and professional programs in a number of STEM fields, including life and physical sciences, mathematics, engineering, agriculture, forestry, nursing, pharmacy, and veterinary medicine. In 2018, out of a total enrollment of 5,812 graduate/professional students, 1,958 , or about $34 \%$, were STEM students. ${ }^{1}$ Given these campus demographics, Auburn University Libraries (AUL) faculty were interested in learning more about the specific research needs of STEM students and exploring how, or whether, these needs differed from those of non-STEM students.

In December 2017, prompted in part by ongoing discussions and self-studies around librarians' evolving liaison roles, AUL librarians decided to move forward with participation in two large user surveys: the Ithaka S+R Faculty survey and the Ithaka S+R Graduate and Professional Student survey. ${ }^{2}$ Library staff recognized that a more in-depth understanding of the research practices of Auburn faculty and graduate students would help librarians prioritize the resources and services that would be of most benefit to these user groups. They selected the Ithaka S+R surveys because they found the surveys' focus on researcher practices and perceptions to be well aligned with these objectives.

Because demographic data gathered by the Ithaka $\mathrm{S}+\mathrm{R}$ Graduate and Professional Student survey included participants' academic programs, the authors of this study saw an opportunity to conduct a comparative analysis of the user needs of STEM and non-STEM students. They decided to focus on three areas of particular relevance for their work as subject liaison librarians: graduate students' patterns of information discovery and usage; their perceptions about the research skills needed for academic and professional success; and their views regarding the library's role in supporting different parts of the research cycle.

\section{Methodology}

In spring 2018, AUL librarians and Ithaka S+R staff prepared to implement local versions of the two surveys. The Graduate and Professional Student survey consists of modules focused on students' goals for their 
higher education experience; their information discovery practices and resource use for coursework and research; and their perceptions of the role of the library in supporting their scholarly work. Library faculty also elected to include two optional survey modules, one focused on graduate students' attitudes toward conducting original research and the other on graduate student roles and activities as members of research groups and labs on campus. (The latter module was administered only to STEM students.)

After obtaining approval for the study from Auburn University's Institutional Review Board (IRB), library staff requested names, emails, and basic demographic information from the campus Office of Institutional Research. Invitations to participate in the survey were emailed to graduate students by Ithaka S+R. Library staff also promoted the survey in the campus graduate student newsletter and through social media on the Graduate Student Council's Facebook page. As an incentive for participation, students who completed the survey could choose to be entered in a drawing to win one of two Apple iPads.

Ithaka S+R distributed email invitations to 5,524 Auburn University graduate and professional students on March 24, 2018. Students received four additional reminder emails before the survey closed on April 29, 2018. About $27 \%(n=1,488)$ of those receiving the email clicked on the survey link; about $24 \%(n=1,337)$ started the survey. The response rate for participants who completed the survey was about $20 \%(n=1,105)$. Due to the survey flow and skip patterns, not all graduate and professional student participants received every question in the survey.

After receiving the Ithaka S+R Graduate and Professional Student survey report and cross tab stratifications of responses by demographic characteristics, the authors identified the specific subset of survey questions they thought were best aligned with their research focus. (See Appendices A, B, and C for lists of the survey questions and responses selected for analysis.) The subpopulation of STEM students was identified using responses to the question, "At this college or university, are you pursuing a degree in a STEM field or discipline?" The survey defines a STEM degree as "a science, technology, engineering or mathematics degree including computer/information sciences, life sciences, physical sciences, health sciences, agricultural sciences, and medical and veterinary fields." Findings of this study are discussed below.

\section{Patterns of Information Use and Discovery}

Ithaka $\mathrm{S}+\mathrm{R}$ survey responses revealed both similarities and differences between STEM and non-STEM graduate students with respect to information use and discovery. Over half of STEM students (60\%) and non-STEM students (59\%) at the coursework stage of their programs found it "easy" or "somewhat easy" to access information needed for coursework and research projects. Among students seeking information for their dissertations, confidence levels were higher for STEM students but lower for non-STEM students. Sixty-six percent of STEM students and 56\% of non-STEM students reported it was "easy" or "somewhat easy" to access information. STEM and non-STEM students diverged to a considerable degree on whether or not they viewed the library as "a starting point" for locating information, resources, or citations. Less than half of STEM students (41\%) "agreed" or "strongly agreed" that the library was "a starting point" for their research while over half of non-STEM students (59\%) held this view (see figure 1). Differences between the types of information used by STEM and non-STEM graduate students may possibly account for differences in their information seeking behaviors. At the coursework stage of their graduate programs, STEM students were more likely than non-STEM students to be making "regular" use of online video tutorials such as Khan Academy, Lynda.com, YouTube (26\% STEM; 22\% non-STEM), and online education resources such as Wikipedia and online study guides (41\% STEM; 35\% non-STEM), as well as other non-library resources. In contrast, non-STEM students at the coursework stage were making "regular" use of sources strongly associated with libraries: print books (48\% non-STEM; 32\% STEM), journal articles (75\% non-STEM; 57\% STEM), and historical documents (10\% non-STEM; 7\% STEM). However, there were also nuances between the two groups in the use of specific source types. For example, while there was a significant difference in the frequency of use of print books by STEM and non-STEM students, the gap closed considerably when students reported on their use of e-books. Over $25 \%$ of STEM students reported "regular" use of e-books, compared to $29 \%$ of non-STEM students. In the case of e-textbooks, the percentage of "regular" use by STEM students was the same as non-STEM (37\% for both groups). 
Figure 1

\section{The library serves as a starting point for locating information, resources, or citations that I use for my coursework or research projects.}

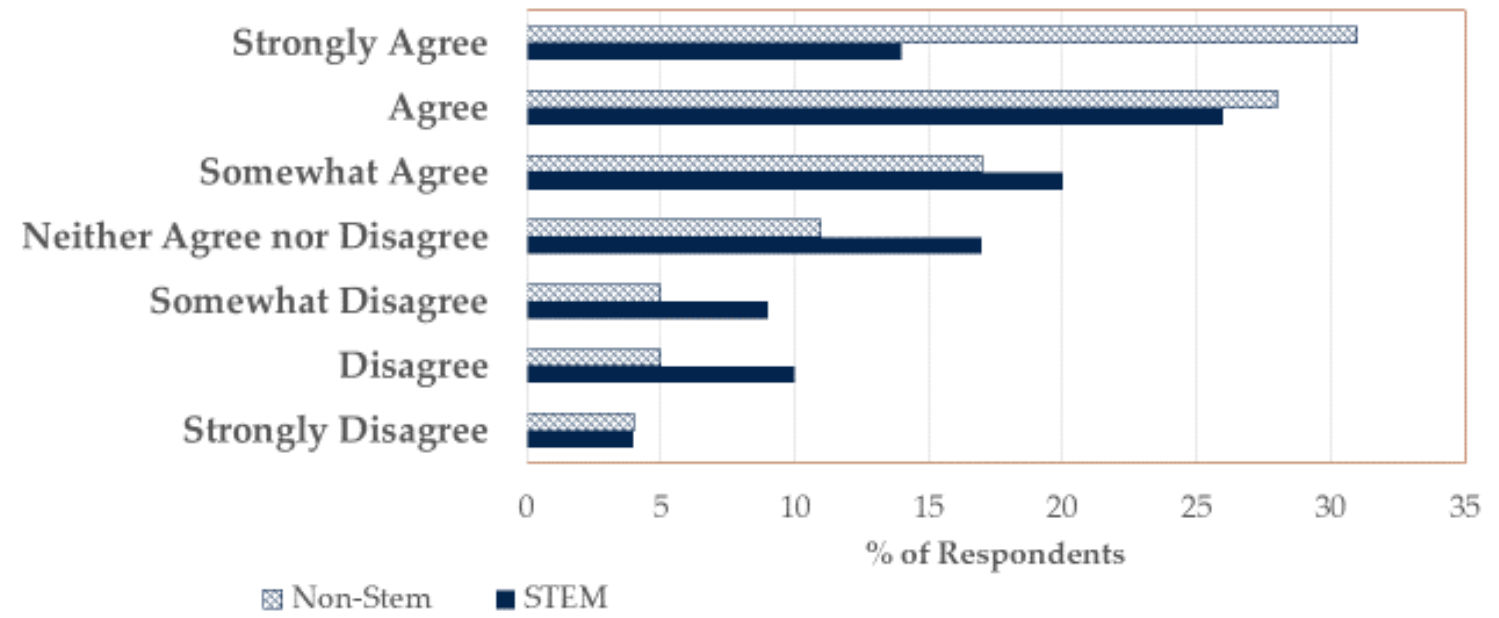

In addition, use of source types shifted as students transitioned from the coursework stage of their programs to the research stage (i.e., either master's paper/capstone project or doctoral dissertation). For STEM students, "regular" use of study guides and online tutorials and education resources was lower while "regular" use of scholarly journals was higher and even surpassed use by non-STEM students (89\% STEM; $82 \%$ non-STEM). Meanwhile, the gap between "regular" use of print books (29\% STEM; 50\% non-STEM) and historical documents (7\% STEM; 22\% non-STEM) was wider between the two groups.

One type of source in which the differences between STEM and non-STEM students was not great was use of data or datasets. At the coursework stage, 34\% of STEM students reported "regular" use of data as compared to $33 \%$ of non-STEM students. At the research stage of graduate work, there was only a slightly wider margin of difference with respect to "regular" use of data (47\% STEM; $42 \%$ non-STEM). A deeper dive into the survey results revealed a significant gap between humanities students' use of data ( $28 \%$ at the research stage) and STEM students; however, regular use of data by social science students was very similar ( $49 \%$ at the research stage) to that of STEM students (see figure 2).

\section{Research Practices and Perceptions}

Both STEM and non-STEM graduate students anticipate that "research and analysis skills" will be "very useful" or "extremely useful" in helping them to secure their desired job or career (83\% STEM; 80\% nonSTEM). A majority in both groups also "agree" or "strongly agree" that their instructors help them to develop the research skills needed to find and use academic sources of information (62\% STEM; 59\% non-STEM). A somewhat lower percentage of students in both groups indicate that library staff play a key role in this area. Among STEM students, this difference in perception is more pronounced. Just over $38 \%$ of STEM students, compared to $45 \%$ of non-STEM students, "agreed" or "strongly agreed" that library staff helped them develop research skills (see figure 3). Graduate students in the humanities, by contrast, were considerably more likely to see library staff as partners in research and, in fact, considered them to be of close-to-equal importance with their instructors in this regard. Over $58 \%$ of humanities students "agreed" or "strongly agreed" that library staff helped with research skills compared to $63 \%$ who "agreed" or "strongly agreed" that their instructors helped. Collaborating with faculty on original research projects provides graduate students with opportunities to be mentored by faculty, and a majority of both STEM and non-STEM graduate students regard it as "important" or "very important" to have this experience before they graduate. STEM students assigned greater importance to this than non-STEM students (67\% STEM; 52\% non-STEM). 
A greater percentage of STEM students also found it to be "important" or "highly important" to be employed or receive college credit as a research assistant (51\% STEM; 30\% non-STEM). STEM students were also more likely to have had these experiences. Over $61 \%$ of STEM students reported collaborating with faculty on original research (compared to $40 \%$ of non-STEM students), and over $45 \%$ of STEM students were employed or received credit as a research assistant (compared with just over $22 \%$ of non-STEM students). Given the culture of collaborative research in the STEM fields, it is perhaps not surprising that STEM students view their instructors as key contributors to their development as researchers.

\section{Figure 2}

\section{How often do you use each of the following types of sources of information in your research projects?}

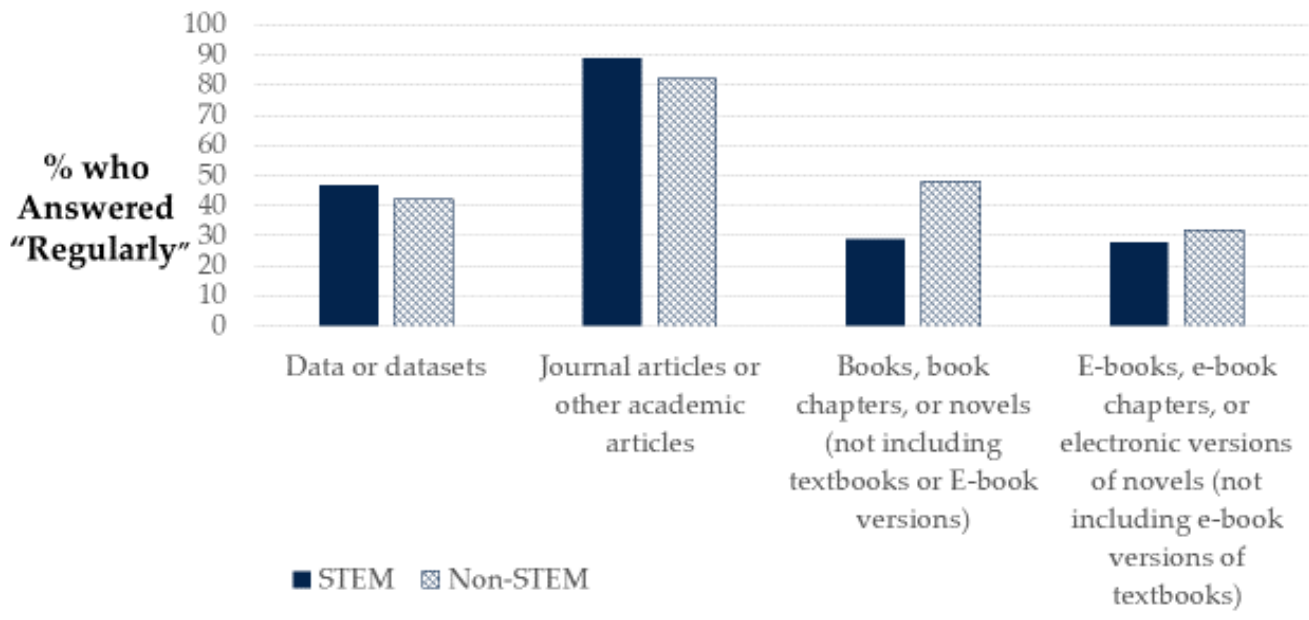

\section{Figure 3}

\section{My instructors help me develop the research skills to find and use academic sources of information}

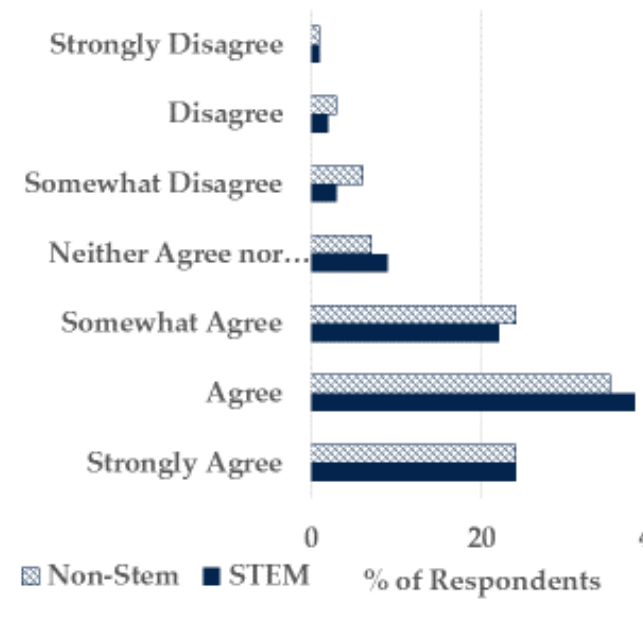

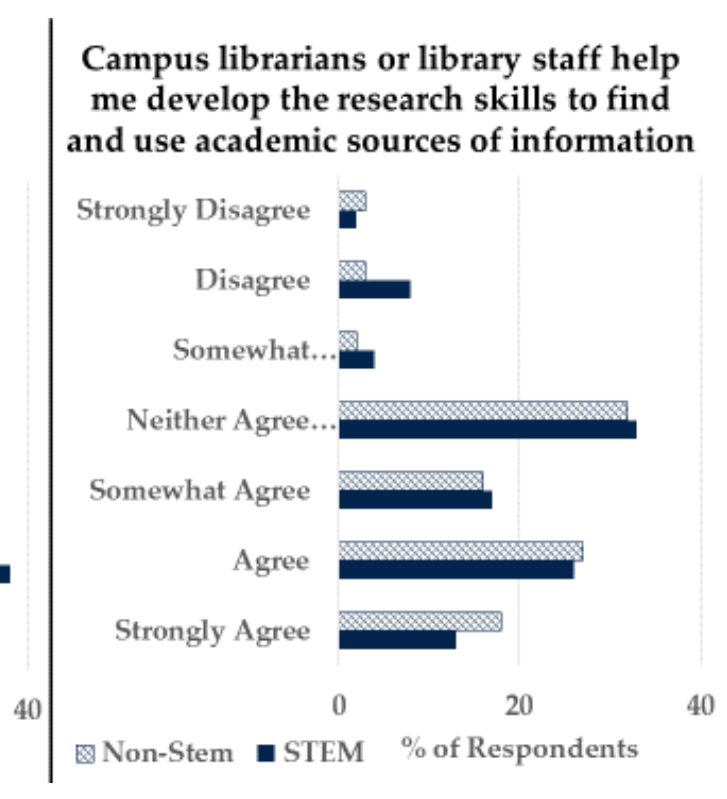

Conducting scholarly research calls for a variety of different research skills. More than eight in ten graduate students, both STEM and non-STEM, rated "locating academic sources of information," "using information ethically (i.e., understanding the concept of intellectual property, copyright issues, and/or legal and ethical standards for the conduct of research)," "writing according to academic or discipline-specific standards," and "forming evidence-based conclusions" as "important" or "highly important" research skills. They also 
rated a number of other research skills as important. Over two-thirds of graduate students, both STEM and non-STEM, consider "evaluating academic sources of information," "synthesizing or incorporating academic information into research projects," "situating research projects within the existing academic literature," "framing or developing original research questions," and "analyzing data, media, images, or other primary source materials" to be "important" or "highly important" research skills. Of somewhat lesser importance to both STEM and non-STEM students were skills related to "writing and submitting grant applications or other funding proposals" and "managing data, media, images or other primary source materials." In general, STEM and non-STEM students were very close in their ratings of the above research skills with the exception of grant writing skills, which STEM students were more likely to rate as "important" or "very important" (61\% STEM; 54\% non-STEM) (see figure 4).

\section{Figure 4}

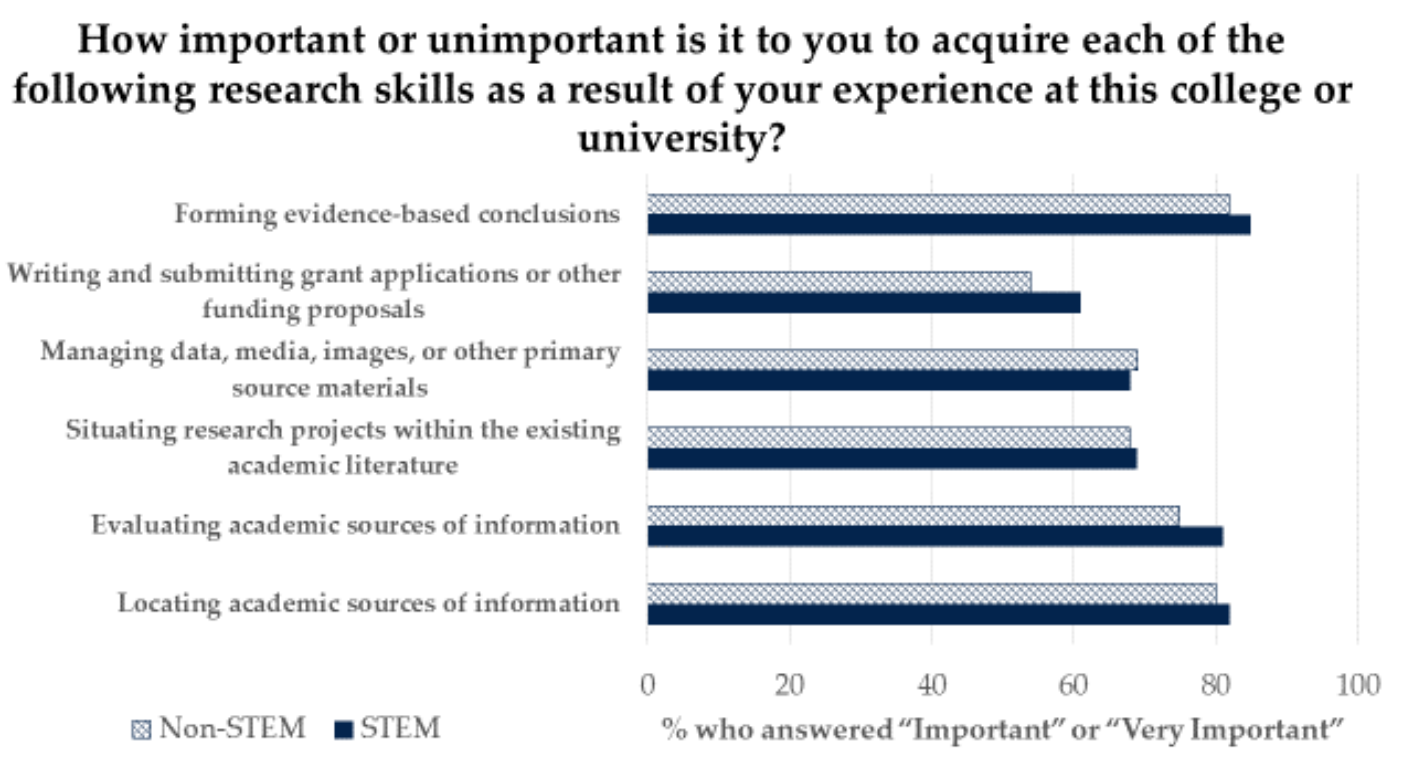

Auburn's local version of the survey also includes a module consisting of questions answered only by STEM students. While this question set does not allow for comparisons with non-STEM students, it does provide context for STEM students' responses about the skills needed to engage in research activity in their disciplines, including many of the skills listed above. For example, $57 \%$ of STEM students ( $n=381)$ responded that they worked in a lab or research group. This subgroup of STEM students answered questions pertaining to their roles in the lab which included "managing, organizing, updating, or analyzing data or datasets" (63\% $\mathrm{PhD}$; 58\% master's/professional); "keeping up to date with the academic literature on behalf of the lab or research group" (49\% PhD; 33\% master's/professional); "managing, organizing, or updating documents on behalf of the lab or research group" (42\% PhD; $26 \%$ master's/professional); and "writing grants or funding proposals" (24\% $\mathrm{PhD}$; $13 \%$ master's/professional) (see figure 5). 


\section{Figure 5}

Within your current lab or research group, which of the following describes your role(s) in the lab or research group? Please select all that apply: (STEM students only)

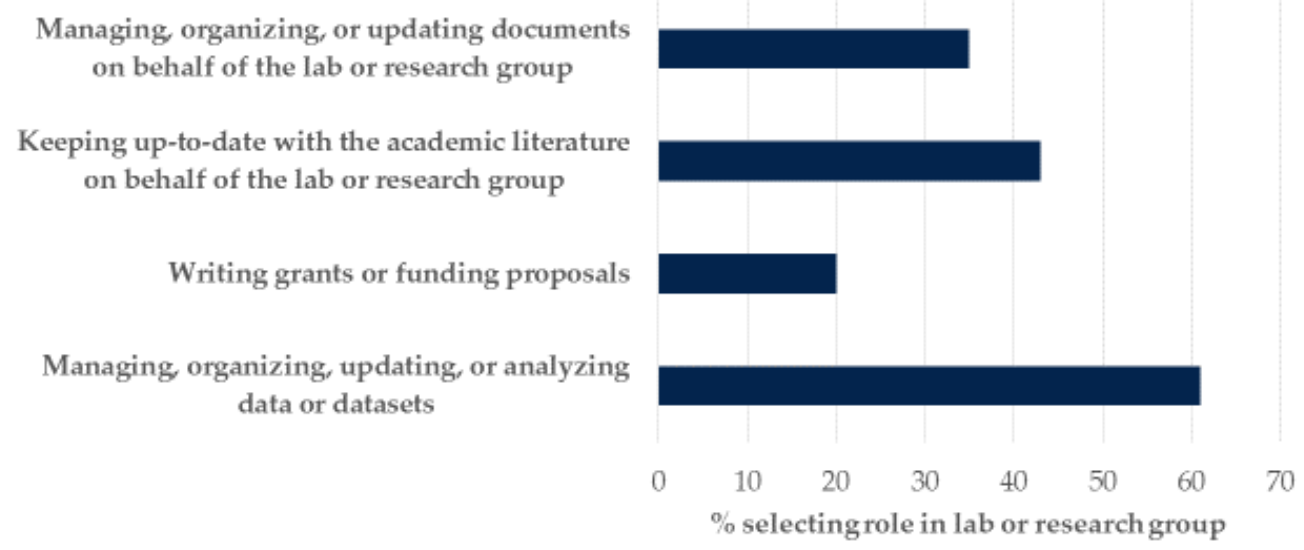

Additional questions probed STEM students' perceptions regarding other skills required to do "cutting edge" work in their chosen job or career. PhD STEM students, in particular, assigned very high levels of usefulness ("extremely useful" or "very useful") to: "proficiency in one or more programming languages" (65\% $\mathrm{PhD}$; $43 \%$ master's/professional); "proficiency in specialized software programs or applications" (76\% $\mathrm{PhD} ; 59 \%$ master's/professional); "proficiency in statistics or applied statistics fields" (79\% PhD; 54\% master's/professional); and "proficiency in data science methodologies" (78\% $\mathrm{PhD} ; 58 \%$ master's/professional).

\section{Graduate Student Perceptions of the Library's Role}

The library role valued most by both STEM and non-STEM graduate students was that "the library pays for resources that I need for my coursework or research projects." This provision of resources was seen as "very useful" or "extremely useful" by nine out of ten STEM (91\%) and non-STEM students (91\%). STEM and nonSTEM students also held generally-similar views about the assistance provided by librarians/library staff with "managing citations of books, articles, data, images, or websites" (63\% STEM; 68\% non-STEM), "using information ethically" (61\% STEM; 65\% non-STEM), and "assistance or guidance with managing data or datasets" (53\% STEM; 58\% non-STEM).

STEM and non-STEM students differed to a greater extent in their perceptions of the usefulness of the library as the place that "stores, organizes, and keeps track of books, articles, data, images, or other resources," with more non-STEM (83\%) than STEM (76\%) students viewing that role as "very useful" or "extremely useful." Approximately three-fourths of non-STEM students view it as "very useful" or "extremely useful" that "the library helps students develop research skills" (73\%) and that "librarians or library staff provide assistance or guidance in finding sources" (76\%). In contrast, closer to two-thirds of STEM students respond "very useful" or "extremely useful" to these questions (61\% and 67\% respectively). Similar degrees of difference exist between the perceptions of STEM and non-STEM students with regard to the usefulness of librarians/library staff providing "help for learning about technological, digital, or online tools" (62\% STEM; 71\% non-STEM) and "support in learning and using online search engines or databases" (66\% STEM; 74\% non-STEM) (see figure 6). 
Figure 6

How useful is it to you personally that your campus library
provides each of the services listed below?

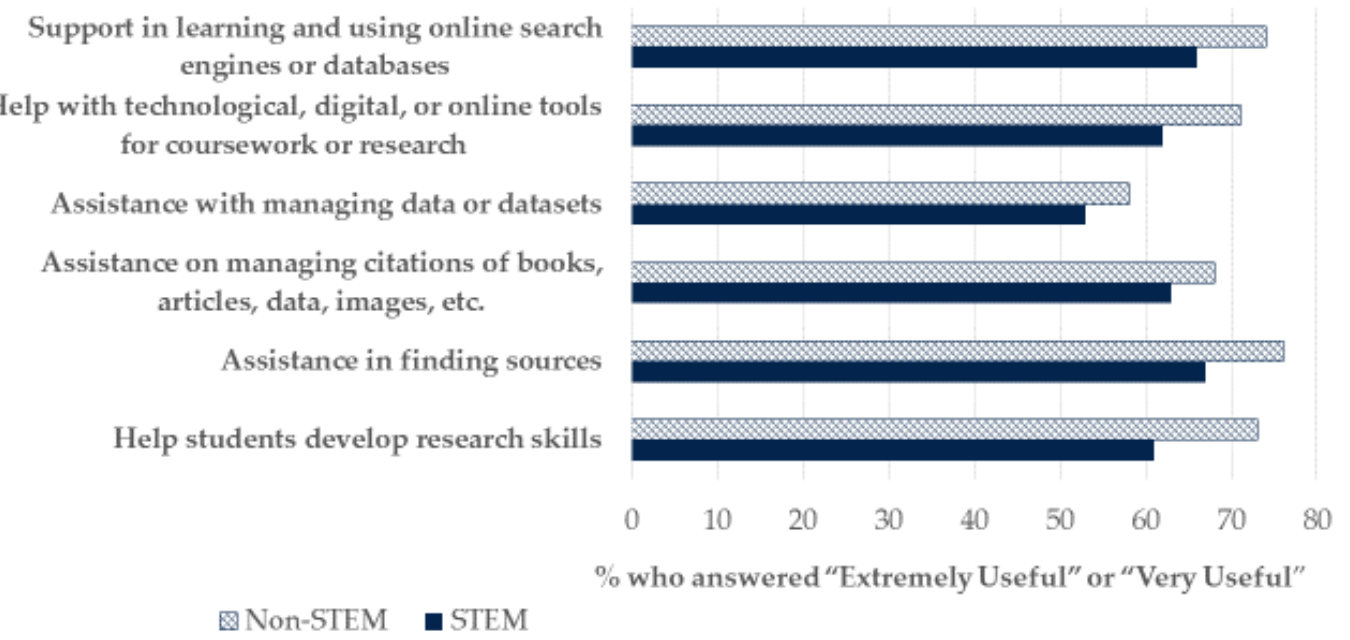

The fact that 39\% of non-STEM students reported having "been directed by a faculty advisor, instructor, or professor to consult with a subject librarian," compared to $28 \%$ of STEM students, may contribute to these differing perceptions about librarians' roles (see figure 7).

\section{Figure 7}

\section{Have you ever been directed by a faculty advisor, instructor, or professor to consult with a subject librarian or departmental library liaison at this college or university?}

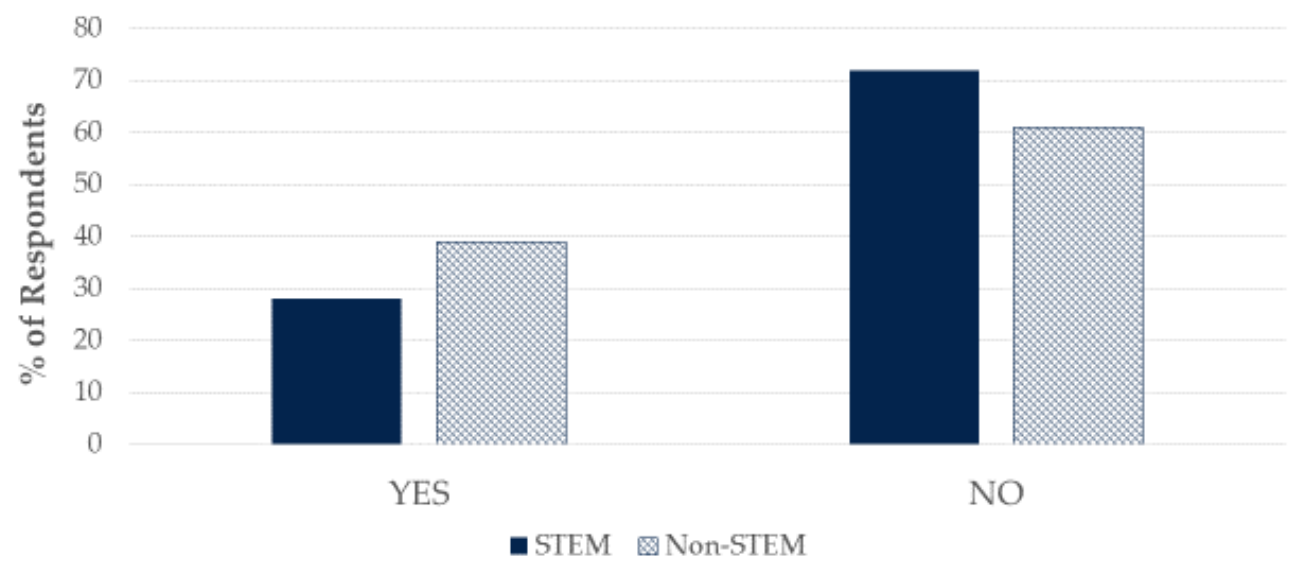

Attendance at library instruction classes may also factor into students' perceptions. Although more than three-fourths of all students reported attending "a library information session, class, or section that was focused on finding sources of information for your major, field, or program of study," the percentage was slightly higher for non-STEM students (75\% STEM; 80\% non-STEM). Moreover, while STEM students were more likely than non-STEM students to have "attended a library information session, class, or section that was taught during an orientation" (55\% STEM; $44 \%$ non-STEM), non-STEM students were more likely to have "attended a library information session, class, or section that was taught by a librarian in a campus library building” (54\% STEM; 65\% non-STEM). It may be that course-integrated library instruction, provided at point of need, has a more positive impact on students' perceptions than instruction provided 
during information-packed orientations. Instruction that takes place in the library building itself may also serve to reinforce the perception of librarians as offering research support.

\section{Custom Liaison Services: Next Steps}

In addition to advanced, discipline-specific knowledge, graduate students in both STEM and non-STEM fields indicated that acquiring research skills was a key goal of their graduate education. Both groups place a premium on a broad range of research competencies that include not only the ability to find reliable sources of information but also other skills deployed throughout the research cycle, such as situating research projects within the existing academic literature, managing citations, using information ethically, managing data, and writing grant proposals. Variations between STEM and non-STEM students with respect to the perceived importance of these general research skills were not great. More noteworthy were the different perceptions STEM and non-STEM students had about the role that librarians played, or could play, in helping students to develop research skills. As the abovementioned responses indicate, STEM students were between 8 and 12\% less likely than their non-STEM counterparts to view librarians as "very useful" or "extremely useful" in helping students to develop research skills, find sources, and learn how to use online search engines or databases. They were also 7\% less likely than non-STEM students to "agree" or "strongly agree" that librarians had helped them to develop research skills.

Given these disparities, STEM students are prime candidates for targeted outreach. The collaborative research culture that exists in the sciences between students and instructors suggests that a promising avenue of approach may be to enlist the aid of STEM faculty. A STEM faculty member's referral is likely to carry considerable weight with his or her students, and the survey data indicates considerable room for improvement in this area. While the STEM module of the survey provides basic information about the research activities of STEM students, follow-up studies would help to fill in more detail about the context in which disciplinary research occurs. This, in turn, would help to bring the specific information needs of STEM students into sharper focus. For example, it would be helpful to know how STEM students understand research skills such as "using information ethically" or "evaluating academic sources of information." General research skills such as these are likely to have disciplinary dimensions that library instructors should attempt to address.

Additional research into disciplinary differences in information usage and discovery patterns would also help to inform library liaison work. As reported, less than half of STEM students (41\%) "agreed" or "strongly agreed" that the library was "a starting point" for their research, compared to $59 \%$ of non-STEM students. How are STEM students locating the scholarly journal content that $89 \%$ are "regularly" using at the research stage of their programs? How heavily are students relying upon Google Scholar or scholarly networking sites such as ResearchGate when conducting research? Anecdotal evidence from Google Scholar workshops held on Auburn's campus suggest that graduate students are often uncertain about the scope of the scholarly literature they are searching and frustrated when they find themselves unable to limit to discipline-specific content-both issues that could be addressed by the library's subject databases.

\section{Conclusion}

As is so often the case with user surveys, responses to the Ithaka S+R Graduate and Professional Student Survey have generated additional research questions. Survey findings have also highlighted areas in which targeted liaison efforts could be of particular benefit to both STEM and non-STEM graduate students. AUL faculty plan to use the survey data to help better position themselves in graduate students' academic and research workflows. Focusing on resources and services that have the greatest impact on these user groups' practices and expectations will help to elevate the library's profile as both partner in research and information content provider.

-Copyright 2019 Adelia Grabowsky and Juliet Rumble 


\section{Notes}

1. STEM demographics are based on the US Immigration and Customs Enforcement (ICE) definition of STEM fields, https://nces.ed.gov/pubs2011/2011226.pdf, last modified April 2011, which is typically used by the Auburn University Office of Institutional Research, https://auburn.edu/administration/ir, accessed January 15, 2019.

2. Ithaka $S+R$ is a non-profit organization that provides assistance with research and evaluation for higher education, libraries, and museums. Information about the Ithaka $\mathrm{S}+\mathrm{R}$ faculty and student surveys is available at: https://sr.ithaka.org/our-work/surveys, accessed January 15, 2019. 


\section{Appendix A}

Question/Answers Related to Patterns of Information Use and Discovery

\begin{tabular}{|c|c|c|c|c|c|c|c|}
\hline \multirow[t]{2}{*}{ Questions } & \multirow[t]{2}{*}{ Answers } & \multicolumn{2}{|c|}{ STEM } & \multicolumn{2}{|c|}{ Non-STEM } & \multicolumn{2}{|c|}{ Total } \\
\hline & & Number & Percentage & Number & Percentage & Number & Percentage \\
\hline \multirow{8}{*}{$\begin{array}{l}\text { How easy or } \\
\text { difficult do } \\
\text { you find it to } \\
\text { access } \\
\text { information } \\
\text { and resources } \\
\text { that you need } \\
\text { for your } \\
\text { coursework } \\
\text { or research } \\
\text { projects? }\end{array}$} & $\begin{array}{l}\text { Very } \\
\text { Difficult }\end{array}$ & 1 & $0.30 \%$ & 0 & $0.00 \%$ & 1 & $0.17 \%$ \\
\hline & Difficult & 8 & $2.42 \%$ & 8 & $3.28 \%$ & 16 & $2.79 \%$ \\
\hline & $\begin{array}{l}\text { Somewhat } \\
\text { Difficult }\end{array}$ & 46 & $13.94 \%$ & 30 & $12.30 \%$ & 76 & $13.24 \%$ \\
\hline & $\begin{array}{l}\text { Neither } \\
\text { Easy nor } \\
\text { Difficult }\end{array}$ & 42 & $12.73 \%$ & 25 & $10.25 \%$ & 67 & $11.67 \%$ \\
\hline & $\begin{array}{l}\text { Somewhat } \\
\text { Easy }\end{array}$ & 97 & $29.39 \%$ & 69 & $28.28 \%$ & 166 & $28.92 \%$ \\
\hline & Easy & 102 & $30.91 \%$ & 75 & $30.74 \%$ & 177 & $30.84 \%$ \\
\hline & Very Easy & 34 & $10.30 \%$ & 37 & $15.16 \%$ & 71 & $12.37 \%$ \\
\hline & TOTAL & 330 & $100.00 \%$ & 244 & $100.00 \%$ & 574 & $100.00 \%$ \\
\hline \multirow{8}{*}{$\begin{array}{l}\text { How easy or } \\
\text { difficult do } \\
\text { you find it to } \\
\text { access } \\
\text { information } \\
\text { and resources } \\
\text { that you need } \\
\text { to prepare or } \\
\text { study for } \\
\text { your PhD or } \\
\text { other } \\
\text { qualifying } \\
\text { exams }\end{array}$} & $\begin{array}{l}\text { Very } \\
\text { Difficult }\end{array}$ & 0 & $0.00 \%$ & 2 & $2.90 \%$ & 2 & $1.12 \%$ \\
\hline & Difficult & 2 & $1.83 \%$ & 1 & $1.45 \%$ & 3 & $1.69 \%$ \\
\hline & $\begin{array}{l}\text { Somewhat } \\
\text { Difficult }\end{array}$ & 9 & $8.26 \%$ & 6 & $8.70 \%$ & 15 & $8.43 \%$ \\
\hline & $\begin{array}{l}\text { Neither } \\
\text { Easy nor } \\
\text { Difficult }\end{array}$ & 18 & $16.51 \%$ & 8 & $11.59 \%$ & 26 & $14.61 \%$ \\
\hline & $\begin{array}{l}\text { Somewhat } \\
\text { Easy }\end{array}$ & 27 & $24.77 \%$ & 15 & $21.74 \%$ & 42 & $23.60 \%$ \\
\hline & Easy & 47 & $43.12 \%$ & 27 & $39.13 \%$ & 74 & $41.57 \%$ \\
\hline & Very Easy & 6 & $5.50 \%$ & 10 & $14.49 \%$ & 16 & $8.99 \%$ \\
\hline & TOTAL & 109 & $100.00 \%$ & 69 & $100.00 \%$ & 178 & $100.00 \%$ \\
\hline
\end{tabular}




\begin{tabular}{|c|c|c|c|c|c|c|c|}
\hline Questions & Answers & & EM & & STEM & & otal \\
\hline $\begin{array}{l}\text { The library } \\
\text { serves as a }\end{array}$ & $\begin{array}{l}\text { Strongly } \\
\text { Disagree }\end{array}$ & 24 & $3.60 \%$ & 18 & $4.27 \%$ & 42 & $3.86 \%$ \\
\hline for locating & Disagree & 63 & $9.45 \%$ & 19 & $4.50 \%$ & 82 & $7.53 \%$ \\
\hline $\begin{array}{l}\text { resources, or } \\
\text { citations that }\end{array}$ & $\begin{array}{l}\text { Somewhat } \\
\text { Disagree }\end{array}$ & 60 & $9.00 \%$ & 20 & $4.74 \%$ & 80 & $7.35 \%$ \\
\hline $\begin{array}{l}\text { coursework } \\
\text { or research } \\
\text { projects. }\end{array}$ & $\begin{array}{l}\text { Neither } \\
\text { Agree nor } \\
\text { Disagree }\end{array}$ & 116 & $17.39 \%$ & 45 & $10.66 \%$ & 161 & $14.78 \%$ \\
\hline & $\begin{array}{l}\text { Somewhat } \\
\text { Agree }\end{array}$ & 133 & $19.94 \%$ & 71 & $16.82 \%$ & 204 & $18.73 \%$ \\
\hline & Agree & 176 & $26.39 \%$ & 120 & $28.44 \%$ & 296 & $27.18 \%$ \\
\hline & $\begin{array}{l}\text { Strongly } \\
\text { Agree }\end{array}$ & 95 & $14.24 \%$ & 129 & $30.57 \%$ & 224 & $20.57 \%$ \\
\hline & TOTAL & 667 & $100.00 \%$ & 422 & $100.00 \%$ & 1089 & $100.00 \%$ \\
\hline In the & Never & 61 & $19.93 \%$ & 37 & $26.43 \%$ & 98 & $21.97 \%$ \\
\hline are currently & Rarely & 77 & $25.16 \%$ & 29 & $20.71 \%$ & 106 & $23.77 \%$ \\
\hline often do you & Sometimes & 103 & $33.66 \%$ & 43 & $30.71 \%$ & 146 & $32.74 \%$ \\
\hline the following & Regularly & 65 & $21.24 \%$ & 31 & $22.14 \%$ & 96 & $21.52 \%$ \\
\hline $\begin{array}{l}\text { sour...- } \\
\text { Online video } \\
\text { tutorials } \\
\text { (such as } \\
\text { videos } \\
\text { available on } \\
\text { Khan } \\
\text { Academy, } \\
\text { Lynda.com, } \\
\text { YouTube, } \\
\text { etc.) }\end{array}$ & TOTAL & 306 & $100.00 \%$ & 140 & $100.00 \%$ & 446 & $100.00 \%$ \\
\hline In the & Never & 41 & $12.35 \%$ & 30 & $12.24 \%$ & 71 & $12.31 \%$ \\
\hline are currently & Rarely & 60 & $18.07 \%$ & 51 & $20.82 \%$ & 111 & $19.24 \%$ \\
\hline often do you & Sometimes & 94 & $28.31 \%$ & 78 & $31.84 \%$ & 172 & $29.81 \%$ \\
\hline $\begin{array}{l}\text { the following } \\
\text { types of }\end{array}$ & Regularly & 137 & $41.27 \%$ & 86 & $35.10 \%$ & 223 & $38.65 \%$ \\
\hline
\end{tabular}




\begin{tabular}{|c|c|c|c|c|c|c|c|}
\hline \multirow[b]{2}{*}{\begin{tabular}{l}
\multicolumn{1}{c}{ Questions } \\
sources- \\
Online \\
educational \\
resources \\
that are not \\
videos (such \\
as Wikipedia, \\
study guides, \\
etc.)
\end{tabular}} & \multirow{2}{*}{$\begin{array}{l}\text { Answers } \\
\text { TOTAL }\end{array}$} & \multicolumn{2}{|c|}{ STEM } & \multicolumn{2}{|c|}{ Non-STEM } & \multicolumn{2}{|c|}{ Total } \\
\hline & & 332 & $100.00 \%$ & 245 & $100.00 \%$ & 577 & $100.00 \%$ \\
\hline \multirow{5}{*}{$\begin{array}{l}\text { In the } \\
\text { courses you } \\
\text { are currently } \\
\text { taking, how } \\
\text { often do you } \\
\text { use each of } \\
\text { the following } \\
\text { types of } \\
\text { sources- } \\
\text { Books, book } \\
\text { chapters, or } \\
\text { novels (not } \\
\text { including } \\
\text { textbooks or } \\
\text { e-book } \\
\text { versions) }\end{array}$} & Never & 90 & $27.19 \%$ & 27 & $11.07 \%$ & 117 & $20.35 \%$ \\
\hline & Rarely & 50 & $15.11 \%$ & 34 & $13.93 \%$ & 84 & $14.61 \%$ \\
\hline & Sometimes & 85 & $25.68 \%$ & 67 & $27.46 \%$ & 152 & $26.43 \%$ \\
\hline & Regularly & 106 & $32.02 \%$ & 116 & $47.54 \%$ & 222 & $38.61 \%$ \\
\hline & TOTAL & 331 & $100.00 \%$ & 244 & $100.00 \%$ & 575 & $100.00 \%$ \\
\hline \multirow{5}{*}{$\begin{array}{l}\text { In the } \\
\text { courses you } \\
\text { are currently } \\
\text { taking, how } \\
\text { often do you } \\
\text { use each of } \\
\text { the following } \\
\text { types of } \\
\text { sources- } \\
\text { Journal } \\
\text { articles or } \\
\text { other } \\
\text { academic } \\
\text { articles }\end{array}$} & Never & 17 & $5.14 \%$ & 5 & $2.05 \%$ & 22 & $3.83 \%$ \\
\hline & Rarely & 37 & $11.18 \%$ & 18 & $7.38 \%$ & 55 & $9.57 \%$ \\
\hline & Sometimes & 88 & $26.59 \%$ & 39 & $15.98 \%$ & 127 & $22.09 \%$ \\
\hline & Regularly & 189 & $57.10 \%$ & 182 & $74.59 \%$ & 371 & $64.52 \%$ \\
\hline & TOTAL & 331 & $100.00 \%$ & 244 & $100.00 \%$ & 575 & $100.00 \%$ \\
\hline \multirow{3}{*}{$\begin{array}{l}\text { In the } \\
\text { courses you } \\
\text { are currently } \\
\text { taking, how } \\
\text { often do you } \\
\text { use each of }\end{array}$} & Never & 217 & $65.76 \%$ & 123 & $50.20 \%$ & 340 & $59.13 \%$ \\
\hline & Rarely & 51 & $15.45 \%$ & 62 & $25.31 \%$ & 113 & $19.65 \%$ \\
\hline & Sometimes & 39 & $11.82 \%$ & 35 & $14.29 \%$ & 74 & $12.87 \%$ \\
\hline
\end{tabular}




\begin{tabular}{|c|c|c|c|c|c|c|c|}
\hline Questions & Answers & & TEM & & STEM & & otal \\
\hline the following & Regularly & 23 & $6.97 \%$ & 25 & $10.20 \%$ & 48 & $8.35 \%$ \\
\hline $\begin{array}{l}\text { sources- } \\
\text { Collection(s) } \\
\text { of historical } \\
\text { documents or } \\
\text { records (such } \\
\text { as rare books, } \\
\text { handwritten } \\
\text { letters or } \\
\text { diaries, } \\
\text { artifacts, etc.) }\end{array}$ & TOTAL & 330 & $100.00 \%$ & 245 & $100.00 \%$ & 575 & $100.00 \%$ \\
\hline In the & Never & 106 & $32.12 \%$ & 57 & $23.27 \%$ & 163 & $28.35 \%$ \\
\hline $\begin{array}{l}\text { are currently } \\
\text { taking, how }\end{array}$ & Rarely & 61 & $18.48 \%$ & 45 & $18.37 \%$ & 106 & $18.43 \%$ \\
\hline $\begin{array}{l}\text { often do you } \\
\text { use each of }\end{array}$ & Sometimes & 80 & $24.24 \%$ & 72 & $29.39 \%$ & 152 & $26.43 \%$ \\
\hline the following & Regularly & 83 & $25.15 \%$ & 71 & $28.98 \%$ & 154 & $26.78 \%$ \\
\hline $\begin{array}{l}\text { sources-e- } \\
\text { books, e-book } \\
\text { chapters, or } \\
\text { electronic } \\
\text { versions of } \\
\text { novels (not } \\
\text { including } \\
\text { textbooks) }\end{array}$ & Total & 330 & $100.00 \%$ & 245 & $100.00 \%$ & 575 & $100.00 \%$ \\
\hline In the & Never & 40 & $12.20 \%$ & 35 & $14.34 \%$ & 75 & $13.11 \%$ \\
\hline $\begin{array}{l}\text { are currently } \\
\text { taking, how }\end{array}$ & Rarely & 62 & $18.90 \%$ & 47 & $19.26 \%$ & 109 & $19.06 \%$ \\
\hline $\begin{array}{l}\text { often do you } \\
\text { use each of }\end{array}$ & Sometimes & 104 & $31.71 \%$ & 72 & $29.51 \%$ & 176 & $30.77 \%$ \\
\hline $\begin{array}{l}\text { the following } \\
\text { types of }\end{array}$ & Regularly & 122 & $37.20 \%$ & 90 & $36.89 \%$ & 212 & $37.06 \%$ \\
\hline $\begin{array}{l}\text { sources- } \\
\text { Electronic or } \\
\text { e-book } \\
\text { versions of } \\
\text { textbooks or } \\
\text { textbook } \\
\text { chapters }\end{array}$ & Total & 328 & $100.00 \%$ & 244 & $100.00 \%$ & 572 & $100.00 \%$ \\
\hline $\begin{array}{l}\text { How often do } \\
\text { you use each }\end{array}$ & Never & 34 & $11.11 \%$ & 18 & $12.77 \%$ & 52 & $11.63 \%$ \\
\hline
\end{tabular}




\begin{tabular}{|c|c|c|c|c|c|c|c|}
\hline Questions & Answers & & EM & & STEM & & otal \\
\hline of the & Rarely & 81 & $26.47 \%$ & 32 & $22.70 \%$ & 113 & $25.28 \%$ \\
\hline types of & Sometimes & 98 & $32.03 \%$ & 49 & $34.75 \%$ & 147 & $32.89 \%$ \\
\hline information & Regularly & 93 & $30.39 \%$ & 42 & $29.79 \%$ & 135 & $30.20 \%$ \\
\hline $\begin{array}{l}\text { research } \\
\text { projects- } \\
\text { Online } \\
\text { educational } \\
\text { resources } \\
\text { that are not } \\
\text { videos (such } \\
\text { as Wikipedia, } \\
\text { study guides, } \\
\text { etc.) }\end{array}$ & Total & 306 & $100.00 \%$ & 141 & $100.00 \%$ & 447 & $100.00 \%$ \\
\hline How often do & Never & 2 & $0.65 \%$ & 1 & $0.71 \%$ & 3 & $0.67 \%$ \\
\hline $\begin{array}{l}\text { of the } \\
\text { following }\end{array}$ & Rarely & 5 & $1.63 \%$ & 2 & $1.42 \%$ & 7 & $1.56 \%$ \\
\hline types of & Sometimes & 27 & $8.79 \%$ & 23 & $16.31 \%$ & 50 & $11.16 \%$ \\
\hline $\begin{array}{l}\text { information } \\
\text { in vour }\end{array}$ & Regularly & 273 & $88.93 \%$ & 115 & $81.56 \%$ & 388 & $86.61 \%$ \\
\hline $\begin{array}{l}\text { research } \\
\text { projects- } \\
\text { Journal } \\
\text { articles or } \\
\text { other } \\
\text { academic } \\
\text { articles }\end{array}$ & Total & 307 & $100.00 \%$ & 141 & $100.00 \%$ & 448 & $100.00 \%$ \\
\hline How often do & Never & 48 & $15.58 \%$ & 10 & $7.14 \%$ & 58 & $12.95 \%$ \\
\hline $\begin{array}{l}\text { of the } \\
\text { following }\end{array}$ & Rarely & 74 & $24.03 \%$ & 16 & $11.43 \%$ & 90 & $20.09 \%$ \\
\hline $\begin{array}{l}\text { types of } \\
\text { sources of }\end{array}$ & Sometimes & 98 & $31.82 \%$ & 44 & $31.43 \%$ & 142 & $31.70 \%$ \\
\hline $\begin{array}{l}\text { information } \\
\text { in your }\end{array}$ & Regularly & 88 & $28.57 \%$ & 70 & $50.00 \%$ & 158 & $35.27 \%$ \\
\hline
\end{tabular}




\begin{tabular}{|c|c|c|c|c|c|c|c|}
\hline \multirow[b]{2}{*}{\begin{tabular}{l}
\multicolumn{1}{c}{ Questions } \\
research \\
projects- \\
Books, book \\
chapters, or \\
novels that \\
are not \\
textbooks \\
(not \\
including e- \\
book \\
versions)
\end{tabular}} & \multirow{2}{*}{$\begin{array}{l}\text { Answers } \\
\text { Total }\end{array}$} & \multicolumn{2}{|c|}{ STEM } & \multicolumn{2}{|c|}{ Non-STEM } & \multicolumn{2}{|c|}{ Total } \\
\hline & & 308 & $100.00 \%$ & 140 & $100.00 \%$ & 448 & $100.00 \%$ \\
\hline \multirow{5}{*}{$\begin{array}{l}\text { How often do } \\
\text { you use each } \\
\text { of the } \\
\text { following } \\
\text { types of } \\
\text { sources of } \\
\text { information } \\
\text { in your } \\
\text { research } \\
\text { projects- } \\
\text { Collection(s) } \\
\text { of historical } \\
\text { documents or } \\
\text { records (such } \\
\text { as rare books, } \\
\text { handwritten } \\
\text { letters or } \\
\text { diaries, } \\
\text { artifacts, etc.) }\end{array}$} & Never & 144 & $46.75 \%$ & 39 & $28.06 \%$ & 183 & $40.94 \%$ \\
\hline & Rarely & 102 & $33.12 \%$ & 38 & $27.34 \%$ & 140 & $31.32 \%$ \\
\hline & Sometimes & 40 & $12.99 \%$ & 32 & $23.02 \%$ & 72 & $16.11 \%$ \\
\hline & Regularly & 22 & $7.14 \%$ & 30 & $21.58 \%$ & 52 & $11.63 \%$ \\
\hline & Total & 308 & $100.00 \%$ & 139 & $100.00 \%$ & 447 & $100.00 \%$ \\
\hline \multirow{5}{*}{$\begin{array}{l}\text { In the } \\
\text { courses you } \\
\text { are currently } \\
\text { taking, how } \\
\text { often do you } \\
\text { use each of } \\
\text { the following } \\
\text { types of } \\
\text { sources- } \\
\text { Data or } \\
\text { datasets }\end{array}$} & Never & 48 & $14.55 \%$ & 31 & $12.65 \%$ & 79 & $13.74 \%$ \\
\hline & Rarely & 59 & $17.88 \%$ & 52 & $21.22 \%$ & 111 & $19.30 \%$ \\
\hline & Sometimes & 102 & $30.91 \%$ & 81 & $33.06 \%$ & 183 & $31.83 \%$ \\
\hline & Regularly & 121 & $36.67 \%$ & 81 & $33.06 \%$ & 202 & $35.13 \%$ \\
\hline & Total & 330 & $100.00 \%$ & 245 & $100.00 \%$ & 575 & $100.00 \%$ \\
\hline \multirow{2}{*}{$\begin{array}{l}\text { How often do } \\
\text { you use each } \\
\text { of the } \\
\text { following }\end{array}$} & Never & 17 & $5.52 \%$ & 8 & $5.76 \%$ & 25 & $5.59 \%$ \\
\hline & Rarely & 45 & $14.61 \%$ & 23 & $16.55 \%$ & 68 & $15.21 \%$ \\
\hline
\end{tabular}




\begin{tabular}{|c|c|c|c|c|c|c|c|}
\hline Questions & Answers & \multicolumn{2}{|c|}{ STEM } & \multicolumn{2}{|c|}{ Non-STEM } & \multicolumn{2}{|c|}{ Total } \\
\hline \multirow{3}{*}{$\begin{array}{l}\text { types of } \\
\text { sources of } \\
\text { information } \\
\text { in your } \\
\text { research } \\
\text { projects- } \\
\text { Data or } \\
\text { datasets }\end{array}$} & Sometimes & 100 & $32.47 \%$ & 49 & $35.25 \%$ & 149 & $33.33 \%$ \\
\hline & Regularly & 146 & $47.40 \%$ & 59 & $42.45 \%$ & 205 & $45.86 \%$ \\
\hline & Total & 308 & $100.00 \%$ & 13 & $100.00 \%$ & 447 & $100.00 \%$ \\
\hline
\end{tabular}




\section{Appendix B}

Questions/Answers Related to Research Practices and Perceptions

\begin{tabular}{|c|c|c|c|c|c|c|c|}
\hline \multirow[t]{2}{*}{ Questions } & \multirow[t]{2}{*}{ Answers } & \multicolumn{2}{|c|}{ STEM } & \multicolumn{2}{|c|}{ Non-STEM } & \multicolumn{2}{|c|}{ Total } \\
\hline & & Number & $\%$ & Number & $\%$ & Number & $\%$ \\
\hline \multirow{6}{*}{$\begin{array}{l}\text { How useful do } \\
\text { you think each } \\
\text { of the } \\
\text { following } \\
\text { factors will be } \\
\text { in helping you } \\
\text { get your } \\
\text { desired job or } \\
\text { career? - The } \\
\text { research and } \\
\text { analysis skills } \\
\text { that I acquired } \\
\text { or expect to } \\
\text { acquire at this } \\
\text { college or } \\
\text { university }\end{array}$} & $\begin{array}{l}\text { Not at all } \\
\text { Useful }\end{array}$ & 7 & $1.05 \%$ & 6 & $1.42 \%$ & 13 & $1.19 \%$ \\
\hline & $\begin{array}{l}\text { Not too } \\
\text { Useful }\end{array}$ & 21 & $3.14 \%$ & 20 & $4.73 \%$ & 41 & $3.76 \%$ \\
\hline & $\begin{array}{l}\text { Somewhat } \\
\text { Useful }\end{array}$ & 84 & $12.57 \%$ & 57 & $13.48 \%$ & 141 & $12.92 \%$ \\
\hline & Very Useful & 240 & $35.93 \%$ & 166 & $39.24 \%$ & 406 & $37.21 \%$ \\
\hline & $\begin{array}{l}\text { Extremely } \\
\text { Useful }\end{array}$ & 316 & $47.31 \%$ & 174 & $41.13 \%$ & 490 & $44.91 \%$ \\
\hline & Total & 668 & $100.00 \%$ & 423 & $100.00 \%$ & 1091 & $100.00 \%$ \\
\hline \multirow{8}{*}{$\begin{array}{l}\text { My instructors } \\
\text { help me } \\
\text { develop the } \\
\text { research skills } \\
\text { to find and use } \\
\text { academic } \\
\text { sources of } \\
\text { information for } \\
\text { my coursework } \\
\text { or research } \\
\text { projects. }\end{array}$} & $\begin{array}{l}\text { Strongly } \\
\text { Disagree }\end{array}$ & 3 & $0.93 \%$ & 2 & $0.83 \%$ & 5 & $0.89 \%$ \\
\hline & Disagree & 7 & $2.18 \%$ & 7 & $2.89 \%$ & 14 & $2.49 \%$ \\
\hline & $\begin{array}{l}\text { Somewhat } \\
\text { Disagree }\end{array}$ & 11 & $3.43 \%$ & 15 & $6.20 \%$ & 26 & $4.62 \%$ \\
\hline & $\begin{array}{l}\text { Neither } \\
\text { Agree nor } \\
\text { Disagree }\end{array}$ & 30 & $9.35 \%$ & 17 & $7.02 \%$ & 47 & $8.35 \%$ \\
\hline & $\begin{array}{l}\text { Somewhat } \\
\text { Agree }\end{array}$ & 70 & $21.81 \%$ & 58 & $23.97 \%$ & 128 & $22.74 \%$ \\
\hline & Agree & 122 & $38.01 \%$ & 84 & $34.71 \%$ & 206 & $36.59 \%$ \\
\hline & $\begin{array}{l}\text { Strongly } \\
\text { Agree }\end{array}$ & 78 & $24.30 \%$ & 59 & $24.38 \%$ & 137 & $24.33 \%$ \\
\hline & Total & 321 & $100.00 \%$ & 242 & $100.00 \%$ & 563 & $100.00 \%$ \\
\hline $\begin{array}{l}\text { Campus } \\
\text { librarians or } \\
\text { library staff }\end{array}$ & $\begin{array}{l}\text { Strongly } \\
\text { Disagree }\end{array}$ & 16 & $2.40 \%$ & 12 & $2.86 \%$ & 28 & $2.58 \%$ \\
\hline
\end{tabular}




\begin{tabular}{|c|c|c|c|c|c|c|c|}
\hline Questions & Answers & & $\mathrm{M}$ & & TEM & & \\
\hline help me & Disagree & 38 & $5.70 \%$ & 12 & $2.86 \%$ & 50 & $4.60 \%$ \\
\hline $\begin{array}{l}\text { research skills } \\
\text { to find and use }\end{array}$ & $\begin{array}{l}\text { Somewhat } \\
\text { Disagree }\end{array}$ & 28 & $4.20 \%$ & 7 & $1.67 \%$ & 35 & $3.22 \%$ \\
\hline $\begin{array}{l}\text { sources of } \\
\text { information for } \\
\text { my coursework }\end{array}$ & $\begin{array}{l}\text { Neither } \\
\text { Agree nor } \\
\text { Disagree }\end{array}$ & 218 & $32.68 \%$ & 133 & $31.74 \%$ & 351 & $32.32 \%$ \\
\hline projects & $\begin{array}{l}\text { Somewhat } \\
\text { Agree }\end{array}$ & 111 & $16.64 \%$ & 65 & $15.51 \%$ & 176 & $16.21 \%$ \\
\hline & Agree & 172 & $25.79 \%$ & 115 & $27.45 \%$ & 287 & $26.43 \%$ \\
\hline & $\begin{array}{l}\text { Strongly } \\
\text { Agree }\end{array}$ & 84 & $12.59 \%$ & 75 & $17.90 \%$ & 159 & $14.64 \%$ \\
\hline & Total & 667 & $100.00 \%$ & 419 & $100.00 \%$ & 1086 & $100.00 \%$ \\
\hline $\begin{array}{l}\text { How } \\
\text { important or }\end{array}$ & $\begin{array}{l}\text { Very } \\
\text { Unimportant }\end{array}$ & 51 & $7.67 \%$ & 39 & $9.31 \%$ & 90 & $8.30 \%$ \\
\hline it to you to do & Unimportant & 21 & $3.16 \%$ & 40 & $9.55 \%$ & 61 & $5.63 \%$ \\
\hline $\begin{array}{l}\text { following } \\
\text { before you }\end{array}$ & $\begin{array}{l}\text { Somewhat } \\
\text { Unimportant }\end{array}$ & 18 & $2.71 \%$ & 12 & $2.86 \%$ & 30 & $2.77 \%$ \\
\hline $\begin{array}{l}\text { this } \\
\text { university- } \\
\text { Collaborate on } \\
\text { an original }\end{array}$ & $\begin{array}{l}\text { Neither } \\
\text { Important } \\
\text { nor } \\
\text { Unimportant }\end{array}$ & 65 & $9.77 \%$ & 50 & $11.93 \%$ & 115 & $10.61 \%$ \\
\hline & $\begin{array}{l}\text { Somewhat } \\
\text { Important }\end{array}$ & 64 & $9.62 \%$ & 62 & $14.80 \%$ & 126 & $11.62 \%$ \\
\hline $\begin{array}{l}\text { advisors, } \\
\text { instructors }\end{array}$ & Important & 147 & $22.11 \%$ & 77 & $18.38 \%$ & 224 & $20.66 \%$ \\
\hline professors & $\begin{array}{l}\text { Very } \\
\text { Important }\end{array}$ & 299 & $44.96 \%$ & 139 & $33.17 \%$ & 438 & $40.41 \%$ \\
\hline $\begin{array}{l}\text { How } \\
\text { important or }\end{array}$ & $\begin{array}{l}\text { Very } \\
\text { Unimportant }\end{array}$ & 76 & $11.46 \%$ & 62 & $14.73 \%$ & 138 & $12.73 \%$ \\
\hline $\begin{array}{l}\text { it to you to do } \\
\text { each of the }\end{array}$ & Unimportant & 46 & $6.94 \%$ & 62 & $14.73 \%$ & 108 & $9.96 \%$ \\
\hline $\begin{array}{l}\text { following } \\
\text { before you } \\
\text { graduate from }\end{array}$ & $\begin{array}{l}\text { Somewhat } \\
\text { Unimportant }\end{array}$ & 26 & $3.92 \%$ & 27 & $6.41 \%$ & 53 & $4.89 \%$ \\
\hline
\end{tabular}




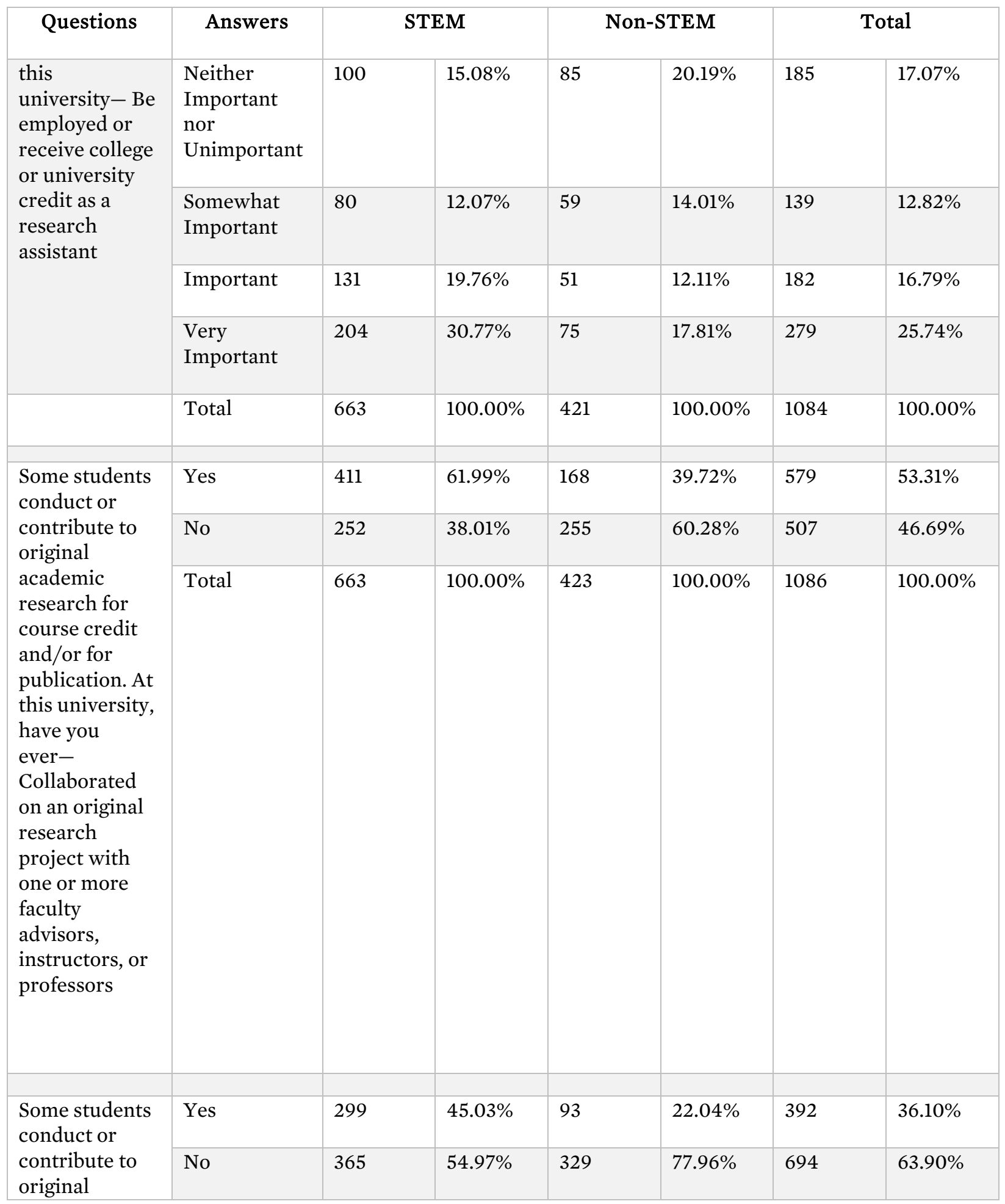




\begin{tabular}{|c|c|c|c|c|c|c|c|}
\hline Questions & Answers & & & & TEM & & \\
\hline $\begin{array}{l}\text { academic } \\
\text { research for } \\
\text { course credit } \\
\text { and/or for } \\
\text { publication. At } \\
\text { this university, } \\
\text { have you } \\
\text { ever- Been } \\
\text { employed or } \\
\text { received } \\
\text { college or } \\
\text { university } \\
\text { credit as a } \\
\text { research } \\
\text { assistant }\end{array}$ & Total & 664 & $100.00 \%$ & 422 & $100.00 \%$ & 1086 & $100.00 \%$ \\
\hline $\begin{array}{l}\text { How } \\
\text { important or }\end{array}$ & $\begin{array}{l}\text { Very } \\
\text { Unimportant }\end{array}$ & 9 & $1.35 \%$ & 4 & $0.95 \%$ & 13 & $1.20 \%$ \\
\hline it to you to & Unimportant & 6 & $0.90 \%$ & 6 & $1.43 \%$ & 12 & $1.11 \%$ \\
\hline & $\begin{array}{l}\text { Somewhat } \\
\text { Unimportant }\end{array}$ & 4 & $0.60 \%$ & 7 & $1.67 \%$ & 11 & $1.01 \%$ \\
\hline $\begin{array}{l}\text { your } \\
\text { experience at } \\
\text { this } \\
\text { university- }\end{array}$ & $\begin{array}{l}\text { Neither } \\
\text { Important } \\
\text { nor } \\
\text { Unimportant }\end{array}$ & 31 & $4.66 \%$ & 17 & $4.05 \%$ & 48 & $4.42 \%$ \\
\hline $\begin{array}{l}\text { academic } \\
\text { sources of }\end{array}$ & $\begin{array}{l}\text { Somewhat } \\
\text { Important }\end{array}$ & 69 & $10.38 \%$ & 50 & $11.90 \%$ & 119 & $10.97 \%$ \\
\hline & Important & 212 & $31.88 \%$ & 109 & $25.95 \%$ & 321 & $29.59 \%$ \\
\hline & $\begin{array}{l}\text { Very } \\
\text { Important }\end{array}$ & 334 & $50.23 \%$ & 227 & $54.05 \%$ & 561 & $51.71 \%$ \\
\hline & Total & 665 & $100.00 \%$ & 420 & $100.00 \%$ & 1085 & $100.00 \%$ \\
\hline $\begin{array}{l}\text { How } \\
\text { important or }\end{array}$ & $\begin{array}{l}\text { Very } \\
\text { Unimportant }\end{array}$ & 11 & $1.65 \%$ & 9 & $2.14 \%$ & 20 & $1.84 \%$ \\
\hline it to you to & Unimportant & 5 & $0.75 \%$ & 5 & $1.19 \%$ & 10 & $0.92 \%$ \\
\hline $\begin{array}{l}\text { the following } \\
\text { research skills } \\
\text { as a result of }\end{array}$ & $\begin{array}{l}\text { Somewhat } \\
\text { Unimportant }\end{array}$ & 9 & $1.35 \%$ & 8 & $1.90 \%$ & 17 & $1.57 \%$ \\
\hline
\end{tabular}




\begin{tabular}{|c|c|c|c|c|c|c|c|}
\hline Questions & Answers & & & & TEM & & \\
\hline $\begin{array}{l}\text { your } \\
\text { experience at } \\
\text { this } \\
\text { university- }\end{array}$ & $\begin{array}{l}\text { Neither } \\
\text { Important } \\
\text { nor } \\
\text { Unimportant }\end{array}$ & 22 & $3.31 \%$ & 16 & $3.80 \%$ & 38 & $3.50 \%$ \\
\hline information & $\begin{array}{l}\text { Somewhat } \\
\text { Important }\end{array}$ & 70 & $10.53 \%$ & 42 & $9.98 \%$ & 112 & $10.31 \%$ \\
\hline the concept of & Important & 198 & $29.77 \%$ & 110 & $26.13 \%$ & 308 & $28.36 \%$ \\
\hline $\begin{array}{l}\text { property, } \\
\text { copyright }\end{array}$ & $\begin{array}{l}\text { Very } \\
\text { Important }\end{array}$ & 350 & $52.63 \%$ & 231 & $54.87 \%$ & 581 & $53.50 \%$ \\
\hline & Total & 665 & $100.00 \%$ & 421 & $100.00 \%$ & 1086 & $100.00 \%$ \\
\hline $\begin{array}{l}\text { How } \\
\text { important or }\end{array}$ & $\begin{array}{l}\text { Very } \\
\text { Unimportant }\end{array}$ & 12 & $1.80 \%$ & 10 & $2.38 \%$ & 22 & $2.02 \%$ \\
\hline it to you to & Unimportant & 9 & $1.35 \%$ & 7 & $1.66 \%$ & 16 & $1.47 \%$ \\
\hline $\begin{array}{l}\text { the following } \\
\text { research skills }\end{array}$ & $\begin{array}{l}\text { Somewhat } \\
\text { Unimportant }\end{array}$ & 12 & $1.80 \%$ & 4 & $0.95 \%$ & 16 & $1.47 \%$ \\
\hline $\begin{array}{l}\text { your } \\
\text { experience at } \\
\text { this } \\
\text { university- }\end{array}$ & $\begin{array}{l}\text { Neither } \\
\text { Important } \\
\text { nor } \\
\text { Unimportant }\end{array}$ & 25 & $3.75 \%$ & 20 & $4.75 \%$ & 45 & $4.14 \%$ \\
\hline $\begin{array}{l}\text { according to } \\
\text { academic or }\end{array}$ & $\begin{array}{l}\text { Somewhat } \\
\text { Important }\end{array}$ & 68 & $10.19 \%$ & 43 & $10.21 \%$ & 111 & $10.20 \%$ \\
\hline specific & Important & 197 & $29.54 \%$ & 114 & $27.08 \%$ & 311 & $28.58 \%$ \\
\hline & $\begin{array}{l}\text { Very } \\
\text { Important }\end{array}$ & 344 & $51.57 \%$ & 223 & $52.97 \%$ & 567 & $52.11 \%$ \\
\hline & Total & 667 & $100.00 \%$ & 421 & $100.00 \%$ & 1088 & $100.00 \%$ \\
\hline $\begin{array}{l}\text { How } \\
\text { important or }\end{array}$ & $\begin{array}{l}\text { Very } \\
\text { Unimportant }\end{array}$ & 10 & $1.50 \%$ & 11 & $2.63 \%$ & 21 & $1.94 \%$ \\
\hline $\begin{array}{l}\text { it to you to } \\
\text { acquire each of }\end{array}$ & Unimportant & 4 & $0.60 \%$ & 4 & $0.96 \%$ & 8 & $0.74 \%$ \\
\hline
\end{tabular}




\begin{tabular}{|c|c|c|c|c|c|c|c|}
\hline Questions & Answers & & $\mathrm{EM}$ & & TEM & & \\
\hline $\begin{array}{l}\text { the following } \\
\text { research skills }\end{array}$ & $\begin{array}{l}\text { Somewhat } \\
\text { Unimportant }\end{array}$ & 3 & $0.45 \%$ & 5 & $1.20 \%$ & 8 & $0.74 \%$ \\
\hline $\begin{array}{l}\text { your } \\
\text { experience at } \\
\text { this } \\
\text { university- }\end{array}$ & $\begin{array}{l}\text { Neither } \\
\text { Important } \\
\text { nor } \\
\text { Unimportant }\end{array}$ & 22 & $3.30 \%$ & 18 & $4.31 \%$ & 40 & $3.69 \%$ \\
\hline $\begin{array}{l}\text { evidence-based } \\
\text { conclusions }\end{array}$ & $\begin{array}{l}\text { Somewhat } \\
\text { Important }\end{array}$ & 61 & $9.16 \%$ & 38 & $9.09 \%$ & 99 & $9.13 \%$ \\
\hline & Important & 173 & $25.98 \%$ & 123 & $29.43 \%$ & 296 & $27.31 \%$ \\
\hline & $\begin{array}{l}\text { Very } \\
\text { Important }\end{array}$ & 393 & $59.01 \%$ & 219 & $52.39 \%$ & 612 & $56.46 \%$ \\
\hline & Total & 666 & $100.00 \%$ & 418 & $100.00 \%$ & 1084 & $100.00 \%$ \\
\hline $\begin{array}{l}\text { How } \\
\text { important or }\end{array}$ & $\begin{array}{l}\text { Very } \\
\text { Unimportant }\end{array}$ & 10 & $1.51 \%$ & 7 & $1.67 \%$ & 17 & $1.57 \%$ \\
\hline it to you to & Unimportant & 4 & $0.60 \%$ & 8 & $1.90 \%$ & 12 & $1.11 \%$ \\
\hline $\begin{array}{l}\text { the following } \\
\text { research skills }\end{array}$ & $\begin{array}{l}\text { Somewhat } \\
\text { Unimportant }\end{array}$ & 5 & $0.75 \%$ & 8 & $1.90 \%$ & 13 & $1.20 \%$ \\
\hline $\begin{array}{l}\text { your } \\
\text { experience at } \\
\text { this } \\
\text { university- }\end{array}$ & $\begin{array}{l}\text { Neither } \\
\text { Important } \\
\text { nor } \\
\text { Unimportant }\end{array}$ & 27 & $4.07 \%$ & 26 & $6.19 \%$ & 53 & $4.89 \%$ \\
\hline $\begin{array}{l}\text { academic } \\
\text { sources of }\end{array}$ & $\begin{array}{l}\text { Somewhat } \\
\text { Important }\end{array}$ & 82 & $12.37 \%$ & 55 & $13.10 \%$ & 137 & $12.65 \%$ \\
\hline & Important & 228 & $34.39 \%$ & 124 & $29.52 \%$ & 352 & $32.50 \%$ \\
\hline & $\begin{array}{l}\text { Very } \\
\text { Important }\end{array}$ & 307 & $46.30 \%$ & 192 & $45.71 \%$ & 499 & $46.08 \%$ \\
\hline & Total & 663 & $100.00 \%$ & 420 & $100.00 \%$ & 1083 & $100.00 \%$ \\
\hline $\begin{array}{l}\text { How } \\
\text { important or } \\
\text { unimportant is }\end{array}$ & $\begin{array}{l}\text { Very } \\
\text { Unimportant }\end{array}$ & 24 & $3.61 \%$ & 15 & $3.58 \%$ & 39 & $3.60 \%$ \\
\hline $\begin{array}{l}\text { it to you to } \\
\text { acquire each of }\end{array}$ & Unimportant & 13 & $1.95 \%$ & 9 & $2.15 \%$ & 22 & $2.03 \%$ \\
\hline
\end{tabular}




\begin{tabular}{|c|c|c|c|c|c|c|c|}
\hline Questions & Answers & & $\mathrm{M}$ & & TEM & & \\
\hline $\begin{array}{l}\text { the following } \\
\text { research skills }\end{array}$ & $\begin{array}{l}\text { Somewhat } \\
\text { Unimportant }\end{array}$ & 7 & $1.05 \%$ & 6 & $1.43 \%$ & 13 & $1.20 \%$ \\
\hline $\begin{array}{l}\text { your } \\
\text { experience at } \\
\text { this } \\
\text { university- }\end{array}$ & $\begin{array}{l}\text { Neither } \\
\text { Important } \\
\text { nor } \\
\text { Unimportant }\end{array}$ & 42 & $6.32 \%$ & 21 & $5.01 \%$ & 63 & $5.81 \%$ \\
\hline $\begin{array}{l}\text { incorporating } \\
\text { academic } \\
\text { information }\end{array}$ & $\begin{array}{l}\text { Somewhat } \\
\text { Important }\end{array}$ & 86 & $12.93 \%$ & 39 & $9.31 \%$ & 125 & $11.53 \%$ \\
\hline into research & Important & 201 & $30.23 \%$ & 123 & $29.36 \%$ & 324 & $29.89 \%$ \\
\hline & $\begin{array}{l}\text { Very } \\
\text { Important }\end{array}$ & 292 & $43.91 \%$ & 206 & $49.16 \%$ & 498 & $45.94 \%$ \\
\hline & Total & 665 & $100.00 \%$ & 419 & $100.00 \%$ & 1084 & $100.00 \%$ \\
\hline $\begin{array}{l}\text { How } \\
\text { important or }\end{array}$ & $\begin{array}{l}\text { Very } \\
\text { Unimportant }\end{array}$ & 19 & $2.85 \%$ & 21 & $5.00 \%$ & 40 & $3.68 \%$ \\
\hline it to you to & Unimportant & 22 & $3.30 \%$ & 13 & $3.10 \%$ & 35 & $3.22 \%$ \\
\hline $\begin{array}{l}\text { the following } \\
\text { research skills }\end{array}$ & $\begin{array}{l}\text { Somewhat } \\
\text { Unimportant }\end{array}$ & 10 & $1.50 \%$ & 8 & $1.90 \%$ & 18 & $1.66 \%$ \\
\hline $\begin{array}{l}\text { your } \\
\text { experience at } \\
\text { this } \\
\text { university- }\end{array}$ & $\begin{array}{l}\text { Neither } \\
\text { Important } \\
\text { nor } \\
\text { Unimportant }\end{array}$ & 58 & $8.70 \%$ & 45 & $10.71 \%$ & 103 & $9.48 \%$ \\
\hline $\begin{array}{l}\text { research } \\
\text { projects within }\end{array}$ & $\begin{array}{l}\text { Somewhat } \\
\text { Important }\end{array}$ & 101 & $15.14 \%$ & 46 & $10.95 \%$ & 147 & $13.52 \%$ \\
\hline academic & Important & 215 & $32.23 \%$ & 103 & $24.52 \%$ & 318 & $29.25 \%$ \\
\hline & $\begin{array}{l}\text { Very } \\
\text { Important }\end{array}$ & 242 & $36.28 \%$ & 184 & $43.81 \%$ & 426 & $39.19 \%$ \\
\hline & Total & 667 & $100.00 \%$ & 420 & $100.00 \%$ & 1087 & $100.00 \%$ \\
\hline $\begin{array}{l}\text { How } \\
\text { important or }\end{array}$ & $\begin{array}{l}\text { Very } \\
\text { Unimportant }\end{array}$ & 20 & $3.02 \%$ & 18 & $4.30 \%$ & 38 & $3.51 \%$ \\
\hline $\begin{array}{l}\text { it to you to } \\
\text { acquire each of }\end{array}$ & Unimportant & 16 & $2.41 \%$ & 13 & $3.10 \%$ & 29 & $2.68 \%$ \\
\hline $\begin{array}{l}\text { the following } \\
\text { research skills } \\
\text { as a result of }\end{array}$ & $\begin{array}{l}\text { Somewhat } \\
\text { Unimportant }\end{array}$ & 18 & $2.71 \%$ & 8 & $1.91 \%$ & 26 & $2.40 \%$ \\
\hline
\end{tabular}




\begin{tabular}{|c|c|c|c|c|c|c|c|}
\hline Questions & Answers & & $\mathbf{M}$ & & TEM & & \\
\hline $\begin{array}{l}\text { your } \\
\text { experience at } \\
\text { this } \\
\text { university- }\end{array}$ & $\begin{array}{l}\text { Neither } \\
\text { Important } \\
\text { nor } \\
\text { Unimportant }\end{array}$ & 44 & $6.64 \%$ & 23 & $5.49 \%$ & 67 & $6.19 \%$ \\
\hline $\begin{array}{l}\text { developing } \\
\text { original }\end{array}$ & $\begin{array}{l}\text { Somewhat } \\
\text { Important }\end{array}$ & 89 & $13.42 \%$ & 53 & $12.65 \%$ & 142 & $13.12 \%$ \\
\hline questions & Important & 179 & $27.00 \%$ & 106 & $25.30 \%$ & 285 & $26.34 \%$ \\
\hline & $\begin{array}{l}\text { Very } \\
\text { Important }\end{array}$ & 297 & $44.80 \%$ & 198 & $47.26 \%$ & 495 & $45.75 \%$ \\
\hline & Total & 663 & $100.00 \%$ & 419 & $100.00 \%$ & 1082 & $100.00 \%$ \\
\hline $\begin{array}{l}\text { How } \\
\text { important or }\end{array}$ & $\begin{array}{l}\text { Very } \\
\text { Unimportant }\end{array}$ & 10 & $1.50 \%$ & 9 & $2.15 \%$ & 19 & $1.75 \%$ \\
\hline it to you to & Unimportant & 8 & $1.20 \%$ & 10 & $2.39 \%$ & 18 & $1.66 \%$ \\
\hline $\begin{array}{l}\text { the following } \\
\text { research skills }\end{array}$ & $\begin{array}{l}\text { Somewhat } \\
\text { Unimportant }\end{array}$ & 10 & $1.50 \%$ & 10 & $2.39 \%$ & 20 & $1.85 \%$ \\
\hline $\begin{array}{l}\text { your } \\
\text { experience at } \\
\text { this } \\
\text { university- }\end{array}$ & $\begin{array}{l}\text { Neither } \\
\text { Important } \\
\text { nor } \\
\text { Unimportant }\end{array}$ & 31 & $4.66 \%$ & 26 & $6.21 \%$ & 57 & $5.26 \%$ \\
\hline $\begin{array}{l}\text { media, images, } \\
\text { or other }\end{array}$ & $\begin{array}{l}\text { Somewhat } \\
\text { Important }\end{array}$ & 79 & $11.88 \%$ & 42 & $10.02 \%$ & 121 & $11.16 \%$ \\
\hline materials & Important & 194 & $29.17 \%$ & 119 & $28.40 \%$ & 313 & $28.87 \%$ \\
\hline & $\begin{array}{l}\text { Very } \\
\text { Important }\end{array}$ & 333 & $50.08 \%$ & 203 & $48.45 \%$ & 536 & $49.45 \%$ \\
\hline & Total & 665 & $100.00 \%$ & 419 & $100.00 \%$ & 1084 & $100.00 \%$ \\
\hline $\begin{array}{l}\text { How } \\
\text { important or }\end{array}$ & $\begin{array}{l}\text { Very } \\
\text { Unimportant }\end{array}$ & 18 & $2.71 \%$ & 21 & $5.01 \%$ & 39 & $3.60 \%$ \\
\hline $\begin{array}{l}\text { it to you to } \\
\text { acquire each of }\end{array}$ & Unimportant & 17 & $2.56 \%$ & 17 & $4.06 \%$ & 34 & $3.14 \%$ \\
\hline $\begin{array}{l}\text { the following } \\
\text { research skills } \\
\text { as a result of }\end{array}$ & $\begin{array}{l}\text { Somewhat } \\
\text { Unimportant }\end{array}$ & 29 & $4.37 \%$ & 19 & $4.53 \%$ & 48 & $4.43 \%$ \\
\hline
\end{tabular}




\begin{tabular}{|c|c|c|c|c|c|c|c|}
\hline \multirow{5}{*}{$\begin{array}{l}\text { Questions } \\
\text { your } \\
\text { experience at } \\
\text { this } \\
\text { university- } \\
\text { Preserving } \\
\text { data, media, } \\
\text { images, or } \\
\text { other primary } \\
\text { source } \\
\text { materials for } \\
\text { the long-term }\end{array}$} & \multirow{2}{*}{\begin{tabular}{l}
\multicolumn{1}{c}{ Answers } \\
Neither \\
Important \\
nor \\
Unimportant
\end{tabular}} & \multicolumn{2}{|c|}{ STEM } & \multicolumn{2}{|c|}{ Non-STEM } & \multicolumn{2}{|c|}{ Total } \\
\hline & & 76 & $11.45 \%$ & 52 & $12.41 \%$ & 128 & $11.82 \%$ \\
\hline & $\begin{array}{l}\text { Somewhat } \\
\text { Important }\end{array}$ & 118 & $17.77 \%$ & 74 & $17.66 \%$ & 192 & $17.73 \%$ \\
\hline & Important & 178 & $26.81 \%$ & 101 & $24.11 \%$ & 279 & $25.76 \%$ \\
\hline & $\begin{array}{l}\text { Very } \\
\text { Important }\end{array}$ & 228 & $34.34 \%$ & 135 & $32.22 \%$ & 363 & $33.52 \%$ \\
\hline & Total & 664 & $100.00 \%$ & 419 & $100.00 \%$ & 1083 & $100.00 \%$ \\
\hline \multirow{8}{*}{$\begin{array}{l}\text { How } \\
\text { important or } \\
\text { unimportant is } \\
\text { it to you to } \\
\text { acquire each of } \\
\text { the following } \\
\text { research skills } \\
\text { as a result of } \\
\text { your } \\
\text { experience at } \\
\text { this } \\
\text { university- } \\
\text { Writing and } \\
\text { submitting } \\
\text { grant } \\
\text { applications or } \\
\text { other funding } \\
\text { proposals }\end{array}$} & $\begin{array}{l}\text { Very } \\
\text { Unimportant }\end{array}$ & 30 & $4.50 \%$ & 26 & $6.19 \%$ & 56 & $5.15 \%$ \\
\hline & Unimportant & 26 & $3.90 \%$ & 17 & $4.05 \%$ & 43 & $3.96 \%$ \\
\hline & $\begin{array}{l}\text { Somewhat } \\
\text { Unimportant }\end{array}$ & 22 & $3.30 \%$ & 17 & $4.05 \%$ & 39 & $3.59 \%$ \\
\hline & $\begin{array}{l}\text { Neither } \\
\text { Important } \\
\text { nor } \\
\text { Unimportant }\end{array}$ & 70 & $10.49 \%$ & 58 & $13.81 \%$ & 128 & $11.78 \%$ \\
\hline & $\begin{array}{l}\text { Somewhat } \\
\text { Important }\end{array}$ & 109 & $16.34 \%$ & 76 & $18.10 \%$ & 185 & $17.02 \%$ \\
\hline & Important & 155 & $23.24 \%$ & 93 & $22.14 \%$ & 248 & $22.82 \%$ \\
\hline & $\begin{array}{l}\text { Very } \\
\text { Important }\end{array}$ & 255 & $38.23 \%$ & 133 & $31.67 \%$ & 388 & $35.69 \%$ \\
\hline & Total & 667 & $100.00 \%$ & 420 & $100.00 \%$ & 1087 & $100.00 \%$ \\
\hline
\end{tabular}


Appendix C

Questions/Answers Related to Graduate Student Perceptions of the Library's Role

\begin{tabular}{|c|c|c|c|c|c|c|c|}
\hline \multirow[t]{2}{*}{ Questions } & \multirow[t]{2}{*}{ Answers } & \multicolumn{2}{|c|}{ STEM } & \multicolumn{2}{|c|}{ Non-STEM } & \multicolumn{2}{|c|}{ TOTAL } \\
\hline & & Number & $\%$ & Number & $\%$ & Number & $\%$ \\
\hline \multirow{6}{*}{$\begin{array}{l}\text { The library pays } \\
\text { for resources that I } \\
\text { need for my } \\
\text { coursework or } \\
\text { research projects, } \\
\text { from academic } \\
\text { journals to books } \\
\text { to electronic } \\
\text { databases }\end{array}$} & $\begin{array}{l}\text { Not Useful } \\
\text { at all }\end{array}$ & 6 & $0.90 \%$ & 5 & $1.19 \%$ & 11 & $1.01 \%$ \\
\hline & $\begin{array}{l}\text { Not too } \\
\text { Useful }\end{array}$ & 7 & $1.05 \%$ & 6 & $1.43 \%$ & 13 & $1.20 \%$ \\
\hline & $\begin{array}{l}\text { Somewhat } \\
\text { Useful }\end{array}$ & 48 & $7.20 \%$ & 28 & $6.68 \%$ & 76 & $7.00 \%$ \\
\hline & $\begin{array}{l}\text { Very } \\
\text { Useful }\end{array}$ & 175 & $26.24 \%$ & 111 & $26.49 \%$ & 286 & $26.34 \%$ \\
\hline & $\begin{array}{l}\text { Extremely } \\
\text { Useful }\end{array}$ & 431 & $64.62 \%$ & 269 & $64.20 \%$ & 700 & $64.46 \%$ \\
\hline & Total & 667 & $100.00 \%$ & 419 & $100.00 \%$ & 1086 & $100.00 \%$ \\
\hline \multirow{6}{*}{$\begin{array}{l}\text { Librarians or } \\
\text { library staff } \\
\text { provide assistance } \\
\text { or guidance on } \\
\text { managing citations } \\
\text { of books, articles, } \\
\text { data, images, or } \\
\text { websites for } \\
\text { coursework or } \\
\text { research projects } \\
\text { (such as for a } \\
\text { bibliography, } \\
\text { works cited, or } \\
\text { index section) }\end{array}$} & $\begin{array}{l}\text { Not Useful } \\
\text { at all }\end{array}$ & 15 & $2.26 \%$ & 12 & $2.86 \%$ & 27 & $2.49 \%$ \\
\hline & $\begin{array}{l}\text { Not too } \\
\text { Useful }\end{array}$ & 71 & $10.68 \%$ & 24 & $5.73 \%$ & 95 & $8.76 \%$ \\
\hline & $\begin{array}{l}\text { Somewhat } \\
\text { Useful }\end{array}$ & 159 & $23.91 \%$ & 100 & $23.87 \%$ & 259 & $23.89 \%$ \\
\hline & $\begin{array}{l}\text { Very } \\
\text { Useful }\end{array}$ & 267 & $40.15 \%$ & 153 & $36.52 \%$ & 420 & $38.75 \%$ \\
\hline & $\begin{array}{l}\text { Extremely } \\
\text { Useful }\end{array}$ & 153 & $23.01 \%$ & 130 & $31.03 \%$ & 283 & $26.11 \%$ \\
\hline & Total & 665 & $100.00 \%$ & 419 & $100.00 \%$ & 1084 & $100.00 \%$ \\
\hline \multirow{3}{*}{$\begin{array}{l}\text { Librarians or } \\
\text { library staff } \\
\text { provide assistance } \\
\text { or guidance on } \\
\text { using information } \\
\text { ethically (such as } \\
\text { to avoid } \\
\text { plagiarism) }\end{array}$} & $\begin{array}{l}\text { Not Useful } \\
\text { at all }\end{array}$ & 21 & $3.18 \%$ & 16 & $3.81 \%$ & 37 & $3.42 \%$ \\
\hline & $\begin{array}{l}\text { Not too } \\
\text { Useful }\end{array}$ & 68 & $10.29 \%$ & 28 & $6.67 \%$ & 96 & $8.88 \%$ \\
\hline & $\begin{array}{l}\text { Somewhat } \\
\text { Useful }\end{array}$ & 168 & $25.42 \%$ & 102 & $24.29 \%$ & 270 & $24.98 \%$ \\
\hline
\end{tabular}




\begin{tabular}{|c|c|c|c|c|c|c|c|}
\hline \multirow[t]{2}{*}{ Questions } & \multirow{2}{*}{$\begin{array}{l}\text { Answers } \\
\text { Very } \\
\text { Useful }\end{array}$} & \multicolumn{2}{|c|}{ STEM } & \multicolumn{2}{|c|}{ Non-STEM } & \multicolumn{2}{|c|}{ TOTAL } \\
\hline & & 239 & $36.16 \%$ & 149 & $35.48 \%$ & 388 & $35.89 \%$ \\
\hline & $\begin{array}{l}\text { Extremely } \\
\text { Useful }\end{array}$ & 165 & $24.96 \%$ & 125 & $29.76 \%$ & 290 & $26.83 \%$ \\
\hline & Total & 661 & $100.00 \%$ & 420 & $100.00 \%$ & 1081 & $100.00 \%$ \\
\hline \multirow{6}{*}{$\begin{array}{l}\text { Librarians or } \\
\text { library staff } \\
\text { provide assistance } \\
\text { or guidance with } \\
\text { managing data or } \\
\text { datasets }\end{array}$} & $\begin{array}{l}\text { Not Useful } \\
\text { at all }\end{array}$ & 30 & $4.52 \%$ & 27 & $6.52 \%$ & 57 & $5.29 \%$ \\
\hline & $\begin{array}{l}\text { Not too } \\
\text { Useful }\end{array}$ & 82 & $12.35 \%$ & 37 & $8.94 \%$ & 119 & $11.04 \%$ \\
\hline & $\begin{array}{l}\text { Somewhat } \\
\text { Useful }\end{array}$ & 198 & $29.82 \%$ & 111 & $26.81 \%$ & 309 & $28.66 \%$ \\
\hline & $\begin{array}{l}\text { Very } \\
\text { Useful }\end{array}$ & 234 & $35.24 \%$ & 143 & $34.54 \%$ & 377 & $34.97 \%$ \\
\hline & $\begin{array}{l}\text { Extremely } \\
\text { Useful }\end{array}$ & 120 & $18.07 \%$ & 96 & $23.19 \%$ & 216 & $20.04 \%$ \\
\hline & Total & 664 & $100.00 \%$ & 414 & $100.00 \%$ & 1078 & $100.00 \%$ \\
\hline \multirow{6}{*}{$\begin{array}{l}\text { The library stores, } \\
\text { organizes, and } \\
\text { keeps track of } \\
\text { books, articles, } \\
\text { data, images, or } \\
\text { other resources }\end{array}$} & $\begin{array}{l}\text { Not Useful } \\
\text { at all }\end{array}$ & 10 & $1.50 \%$ & 6 & $1.43 \%$ & 16 & $1.47 \%$ \\
\hline & $\begin{array}{l}\text { Not too } \\
\text { Useful }\end{array}$ & 24 & $3.59 \%$ & 14 & $3.33 \%$ & 38 & $3.49 \%$ \\
\hline & $\begin{array}{l}\text { Somewhat } \\
\text { Useful }\end{array}$ & 126 & $18.86 \%$ & 48 & $11.40 \%$ & 174 & $15.98 \%$ \\
\hline & $\begin{array}{l}\text { Very } \\
\text { Useful }\end{array}$ & 266 & $39.82 \%$ & 152 & $36.10 \%$ & 418 & $38.38 \%$ \\
\hline & $\begin{array}{l}\text { Extremely } \\
\text { Useful }\end{array}$ & 242 & $36.23 \%$ & 201 & $47.74 \%$ & 443 & $40.68 \%$ \\
\hline & Total & 668 & $100.00 \%$ & 421 & $100.00 \%$ & 1089 & $100.00 \%$ \\
\hline \multirow{2}{*}{$\begin{array}{l}\text { The library helps } \\
\text { students develop } \\
\text { research skills }\end{array}$} & $\begin{array}{l}\text { Not Useful } \\
\text { at all }\end{array}$ & 13 & $1.94 \%$ & 8 & $1.92 \%$ & 21 & $1.94 \%$ \\
\hline & $\begin{array}{l}\text { Not too } \\
\text { Useful }\end{array}$ & 52 & $7.77 \%$ & 28 & $6.73 \%$ & 80 & $7.37 \%$ \\
\hline
\end{tabular}




\begin{tabular}{|c|c|c|c|c|c|c|c|}
\hline \multirow[t]{2}{*}{ Questions } & \multirow{2}{*}{$\begin{array}{l}\text { Answers } \\
\text { Somewhat } \\
\text { Useful }\end{array}$} & \multicolumn{2}{|c|}{ STEM } & \multicolumn{2}{|c|}{ Non-STEM } & \multicolumn{2}{|c|}{ TOTAL } \\
\hline & & 197 & $29.45 \%$ & 77 & $18.51 \%$ & 274 & $25.25 \%$ \\
\hline & $\begin{array}{l}\text { Very } \\
\text { Useful }\end{array}$ & 212 & $31.69 \%$ & 161 & $38.70 \%$ & 373 & $34.38 \%$ \\
\hline & $\begin{array}{l}\text { Extremely } \\
\text { Useful }\end{array}$ & 195 & $29.15 \%$ & 142 & $34.13 \%$ & 337 & $31.06 \%$ \\
\hline & Total & 669 & $100.00 \%$ & 416 & $100.00 \%$ & 1085 & $100.00 \%$ \\
\hline \multirow{6}{*}{$\begin{array}{l}\text { Librarians or } \\
\text { library staff } \\
\text { provide assistance } \\
\text { or guidance in } \\
\text { finding sources for } \\
\text { coursework or } \\
\text { research projects } \\
\text { (such as books, } \\
\text { articles, databases, } \\
\text { websites, etc.) }\end{array}$} & $\begin{array}{l}\text { Not Useful } \\
\text { at all }\end{array}$ & 10 & $1.50 \%$ & 7 & $1.67 \%$ & 17 & $1.57 \%$ \\
\hline & $\begin{array}{l}\text { Not too } \\
\text { Useful }\end{array}$ & 54 & $8.10 \%$ & 23 & $5.49 \%$ & 77 & $7.09 \%$ \\
\hline & $\begin{array}{l}\text { Somewhat } \\
\text { Useful }\end{array}$ & 157 & $23.54 \%$ & 72 & $17.18 \%$ & 229 & $21.09 \%$ \\
\hline & $\begin{array}{l}\text { Very } \\
\text { Useful }\end{array}$ & 271 & $40.63 \%$ & 167 & $39.86 \%$ & 438 & $40.33 \%$ \\
\hline & $\begin{array}{l}\text { Extremely } \\
\text { Useful }\end{array}$ & 175 & $26.24 \%$ & 150 & $35.80 \%$ & 325 & $29.93 \%$ \\
\hline & Total & 667 & $100.00 \%$ & 419 & $100.00 \%$ & 1086 & $100.00 \%$ \\
\hline \multirow{6}{*}{$\begin{array}{l}\text { Librarians or } \\
\text { library staff } \\
\text { provide help for } \\
\text { learning about } \\
\text { technological, } \\
\text { digital, or online } \\
\text { tools for } \\
\text { coursework or } \\
\text { research }\end{array}$} & $\begin{array}{l}\text { Not Useful } \\
\text { at all }\end{array}$ & 17 & $2.56 \%$ & 12 & $2.88 \%$ & 29 & $2.68 \%$ \\
\hline & $\begin{array}{l}\text { Not too } \\
\text { Useful }\end{array}$ & 67 & $10.08 \%$ & 23 & $5.53 \%$ & 90 & $8.33 \%$ \\
\hline & $\begin{array}{l}\text { Somewhat } \\
\text { Useful }\end{array}$ & 170 & $25.56 \%$ & 87 & $20.91 \%$ & 257 & $23.77 \%$ \\
\hline & $\begin{array}{l}\text { Very } \\
\text { Useful }\end{array}$ & 266 & $40.00 \%$ & 176 & $42.31 \%$ & 442 & $40.89 \%$ \\
\hline & Extremely & 145 & $21.80 \%$ & 118 & $28.37 \%$ & 263 & $24.33 \%$ \\
\hline & Total & 665 & $100.00 \%$ & 416 & $100.00 \%$ & 1081 & $100.00 \%$ \\
\hline $\begin{array}{l}\text { Librarians or } \\
\text { library staff } \\
\text { provide support in }\end{array}$ & $\begin{array}{l}\text { Not Useful } \\
\text { at all }\end{array}$ & 18 & $2.72 \%$ & 12 & $2.89 \%$ & 30 & $2.79 \%$ \\
\hline
\end{tabular}




\begin{tabular}{|c|c|c|c|c|c|c|c|}
\hline \multirow{3}{*}{$\begin{array}{l}\quad \text { Questions } \\
\text { learning and using } \\
\text { online search } \\
\text { engines or } \\
\text { databases }\end{array}$} & \multirow{2}{*}{$\begin{array}{l}\text { Answers } \\
\text { Not too } \\
\text { Useful }\end{array}$} & \multicolumn{2}{|c|}{ STEM } & \multicolumn{2}{|c|}{ Non-STEM } & \multicolumn{2}{|c|}{ TOTAL } \\
\hline & & 56 & $8.47 \%$ & 18 & $4.34 \%$ & 74 & $6.88 \%$ \\
\hline & $\begin{array}{l}\text { Somewhat } \\
\text { Useful }\end{array}$ & 154 & $23.30 \%$ & 77 & $18.55 \%$ & 231 & $21.47 \%$ \\
\hline & $\begin{array}{l}\text { Very } \\
\text { Useful }\end{array}$ & 252 & $38.12 \%$ & 167 & $40.24 \%$ & 419 & $38.94 \%$ \\
\hline & $\begin{array}{l}\text { Extremely } \\
\text { Useful }\end{array}$ & 181 & $27.38 \%$ & 141 & $33.98 \%$ & 322 & $29.93 \%$ \\
\hline & Total & 661 & $100.00 \%$ & 415 & $100.00 \%$ & 1076 & $100.00 \%$ \\
\hline Have you ever & Yes & 184 & $27.88 \%$ & 164 & $39.05 \%$ & 348 & $32.22 \%$ \\
\hline $\begin{array}{l}\text { faculty advisor, } \\
\text { instructor, or }\end{array}$ & No & 476 & $72.12 \%$ & 256 & $60.95 \%$ & 732 & $67.78 \%$ \\
\hline $\begin{array}{l}\text { professor to } \\
\text { consult with a } \\
\text { subject librarian or } \\
\text { departmental } \\
\text { library liaison at } \\
\text { this college or } \\
\text { university (i.e., a } \\
\text { librarian who } \\
\text { specializes in your } \\
\text { major, field, or } \\
\text { program of study?) }\end{array}$ & Total & 660 & $100.00 \%$ & 420 & $100.00 \%$ & 1080 & $100.00 \%$ \\
\hline \multirow{3}{*}{$\begin{array}{l}\text { Have you attended } \\
\text { a library } \\
\text { information } \\
\text { session, class, or } \\
\text { section that was- } \\
\text { Focused on finding } \\
\text { sources of } \\
\text { information for } \\
\text { your major, field, } \\
\text { or program of } \\
\text { study? }\end{array}$} & Yes & 281 & $74.73 \%$ & 233 & $79.79 \%$ & 514 & $76.95 \%$ \\
\hline & No & 95 & $25.27 \%$ & 59 & $20.21 \%$ & 154 & $23.05 \%$ \\
\hline & Total & 376 & $100.00 \%$ & 292 & $100.00 \%$ & 668 & $100.00 \%$ \\
\hline $\begin{array}{l}\text { Have you attended } \\
\text { a library }\end{array}$ & Yes & 206 & $54.93 \%$ & 129 & $44.18 \%$ & 335 & $50.22 \%$ \\
\hline
\end{tabular}




\begin{tabular}{|c|c|c|c|c|c|c|c|}
\hline \multirow{2}{*}{\begin{tabular}{l}
\multicolumn{1}{c}{ Questions } \\
information \\
session, class, or \\
section that was- \\
Taught during an \\
orientation?
\end{tabular}} & \multirow{2}{*}{$\begin{array}{l}\text { Answers } \\
\text { No }\end{array}$} & \multicolumn{2}{|c|}{ STEM } & \multicolumn{2}{|c|}{ Non-STEM } & \multicolumn{2}{|c|}{ TOTAL } \\
\hline & & 169 & $45.07 \%$ & 163 & $55.82 \%$ & 332 & $49.78 \%$ \\
\hline & Total & 375 & $100.00 \%$ & 292 & $100.00 \%$ & 667 & $100.00 \%$ \\
\hline \multirow{3}{*}{$\begin{array}{l}\text { Have you attended } \\
\text { a library } \\
\text { information } \\
\text { session, class, or } \\
\text { section that was- } \\
\text { Taught by a } \\
\text { librarian in a } \\
\text { campus library } \\
\text { building? }\end{array}$} & Yes & 203 & $53.99 \%$ & 191 & $64.97 \%$ & 394 & $58.81 \%$ \\
\hline & No & 173 & $46.01 \%$ & 103 & $35.03 \%$ & 276 & $41.19 \%$ \\
\hline & Total & 376 & $100.00 \%$ & 294 & $100.00 \%$ & 670 & $100.00 \%$ \\
\hline
\end{tabular}

